\title{
Platelet-Derived Growth Factor-Mediated Signal Transduction Underlying Astrocyte Proliferation: Site of Ethanol Action
}

\author{
Jia Luo ${ }^{1}$ and Michael W. Miller ${ }^{1,2,3}$ \\ Department of Psychiatry, University of lowa College of Medicine, lowa City, lowa 52242-1000, 2Research Service, \\ Veterans Affairs Medical Center, lowa City, lowa 52246-2208, and ${ }^{3}$ Department of Pharmacology, University of lowa \\ College of Medicine, lowa City, lowa 52242-1109
}

Platelet-derived growth factor (PDGF) is a critical regulator of cell proliferation. Because ethanol inhibits cell proliferation in vivo and in vitro, we hypothesize that ethanol-induced inhibition results from differential interference with signal transduction pathways activated by PDGF. Cultured cortical astrocytes were used to examine the effects of ethanol on PDGF-mediated signal transduction, on the expression of two PDGF monomers (A- and B-chains), and on the expression of two PDGF receptor subunits (PDGF $\alpha r$ and PDGF $\beta r$ ). PDGF-B chain homodimer (PDGF-BB), and to a lesser extent PDGF-A chain homodimer (PDGF-AA), stimulated the proliferation of astrocytes raised in a serum-free medium. Ethanol attenuated these actions in a concentration-dependent manner. Ethanol inhibited both PDGF-AA- and PDGF-BB-mediated phosphorylation of PDGF $\alpha$ r, but it had little effect on PDGF $\beta r$ autophosphorylation. Likewise, ethanol abolished the association of PDGF $\alpha$ r to Ras GTPase-activating protein (Ras-GAP), but it did not affect the binding of Ras-GAP to PDGF $\beta$ r. PDGF stimulated the activities of mitogen-activated protein kinase (MAPK) in protein kinase $\mathrm{C}$ (PKC) independent and dependent manners. Ethanol inhibited the PKC-independent, acute activation of MAPK; however, it stimulated the PKC-dependent, sustained activation of MAPK. The expression of neither ligand was altered by exposure to ethanol for $3 \mathrm{~d}$. Moreover, such treatment specifically upregulated PDGF $\alpha$ r expression in a concentration-dependent manner. It did not, however, affect the binding affinity of either receptor. Thus, the signal transduction pathways initiated by PDGF-AA and PDGF-BB were differentially affected by ethanol. This differential vulnerability resulted from the preferential effects of ethanol on PDGF $\alpha r$ autophosphorylation. Hence, ethanol-induced alterations are transduced through specific receptors of mitogenic growth factors.

Key words: alcohol; cell proliferation; cerebral cortex; fetal alcohol syndrome; glia; MAP kinase; phosphorylation; protein kinase C; Scatchard analysis
Platelet-derived growth factor (PDGF) is mitogenic for many cells (Kohler and Lipton, 1974; Ross et al., 1974; Westermark and Wasteson, 1976; Uren et al., 1994). High amounts of PDGF and their receptors are expressed in the immature brain (Westermark and Wasteson, 1976; Reddy and Pleasure, 1992; Valenzuela et al., 1997). PDGF consists of two monomers: an A-chain (PDGF-AA) and a B-chain (PDGF-BB). In its active form, PDGF is a disulfide-bound dimer of two monomers, and all dimeric combinations (i.e., PDGF-AA, PDGF-AB, and PDGF-BB) exist naturally (Bowen-Pope et al., 1989; Hart et al., 1990; Claesson-Welsh, 1994).

PDGF elicits its biological activity through interactions with transmembrane high-affinity receptors (Claesson-Welsh, 1994). There are two receptor subunits for PDGF: the PDGF $\alpha$ receptor (PDGF $\alpha \mathrm{r}$ ) and the PDGF $\beta$ receptor (PDGF $\beta$ r). Each subunit has a molecular weight of between 170 and $190 \mathrm{kDa}$. The binding of PDGF ligands with their receptors induces the dimerization of the subunits (Ullrich and Schlessinger, 1990). The PDGF $\alpha$ r binds to either the A- or B-chain, whereas the PDGF $\beta$ r only binds to the B-chain (Inui et al., 1994). Thus, PDGF-AA induces the

\footnotetext{
Received May 24, 1999; revised Aug. 25, 1999; accepted Sept. 2, 1999.

This research was funded by the Department of Veterans Affairs and National Institutes of Health (Grants AA 06916, AA 07568, AA 09611, DE 07734, and MH 14620).

Correspondence should be addressed to Michael W. Miller, Department of Psychiatry-M.E.B., University of Iowa College of Medicine, Iowa City, IA 522421000. E-mail: michael-w-miller@uiowa.edu.

Copyright (C) 1999 Society for Neuroscience 0270-6474/99/1910014-12\$05.00/0
}

formation of PDGF $\alpha$ r-PDGF $\alpha$ r homodimers, PDGF-AB can induce PDGF $\alpha \mathrm{r}-\mathrm{PDGF} \alpha \mathrm{r}$ homodimers and PDGF $\alpha \mathrm{r}-\mathrm{PDGF} \beta \mathrm{r}$ heterodimers to form, and PDGF-BB induces the formation of any of the three possible dimers (PDGF $\alpha \mathrm{r}-\mathrm{PDGF} \alpha \mathrm{r}, \mathrm{PDGF} \alpha \mathrm{r}-$ PDGF $\beta$ r, and PDGF $\beta r-P D G F \beta r$ ) (Claesson-Welsh, 1994).

PDGF initiates a defined signal transduction pathway. Both PDGF $\alpha \mathrm{r}$ and PDGF $\beta \mathrm{r}$ are tyrosine kinases. Binding of a PDGF ligand to either PDGF $\alpha$ r or PDGF $\beta r$ induces receptor autophosphorylation (Ek and Heldin, 1982). In turn, stimulation of the PDGF receptor activates an enzyme cascade that includes various phosphorylating enzymes, i.e., protein kinase C (PKC), Ras, Raf, and mitogen-activated protein kinase (MAPK), and ultimately triggers cell division (Bornfeldt et al., 1995; Hart et al., 1995).

Cell proliferation is profoundly depressed by ethanol. In fact, ethanol-induced reductions in cell proliferation are a major cause of the microencephaly characterizing fetal alcohol syndrome (Miller, 1992; Luo and Miller, 1998; Mooney and Miller, 1999). Such inhibitory effects of ethanol may result from interference with mitogenic growth factors, specifically with the PDGF. In vitro studies of various neuroblastoma cells show that ethanol can block the PDGF-mediated proliferation (Luo and Miller, 1997a,b).

Three hypotheses were tested in the present study. (1) Ethanol does not universally affect all PDGF-mediated activities. That is, one PDGF receptor subunit is more susceptible to ethanol toxicity than the other. (2) Ethanol inhibits PDGF-regulated cell proliferation by promoting a state of chronic activation of 
MAPK. (3) Ethanol-induced inhibition of PDGF signaling results in a compensatory alteration of receptor expression.

The present studies focused on immature astrocytes for three reasons. (1) Their proliferation is adversely affected by ethanol (Davies and Vernadakis, 1984; Kennedy and Mukerji, 1986; Guerri et al., 1990; Snyder et al., 1992). (2) Astrocytes respond to PDGF and express PDGF receptors (Nagano et al., 1993; Prins et al., 1996; Valenzuela et al., 1997). (3) Their numbers are significantly reduced in vivo after prenatal exposure to ethanol (Miller and Potempa, 1990). Thus, we used primary cultures of cortical astrocytes to determine the effect of ethanol on the PDGF system.

\section{MATERIALS AND METHODS}

\section{Astrocyte cultures}

Astrocytes were obtained from the neocortices of 4- or 5-d-old rats. Pups were decapitated, and the dorsolateral cortices were carefully removed. Each cortex was immersed in H-EBSS solution $(13.8 \mathrm{~mm} \mathrm{NaCl}, 5.0 \mathrm{~mm}$ $\mathrm{KCl}, 25.0 \mathrm{~mm} \mathrm{HEPES}, 4.2 \mathrm{~mm} \mathrm{NaHCO}{ }_{3}, 1.0 \mathrm{~mm} \mathrm{NaH}_{2} \mathrm{PO}_{4}$, and $0.010 \%$ phenol red). The meninges were removed by rotating tissues on frosted glass, and the tissue was minced with a sterile razor blade. The mash was suspended in $10 \mathrm{ml}$ of a trypsin solution $(0.25 \mathrm{mg} / \mathrm{ml}$ trypsin in H-EBSS $)$ for $15 \mathrm{~min}$ at $37^{\circ} \mathrm{C}$. An equal volume of a solution of DNase (130 Kunitz $\mathrm{U} / \mathrm{ml}$; Sigma, St. Louis, MO) and a trypsin inhibitor $(0.75 \mathrm{mg} / \mathrm{ml}$; Sigma $)$ was added to halt trypsin activity. A brief $(5 \mathrm{sec})$ centrifugation sedimented the blocks. The tissue was triturated through a Pasteur pipette to produce a cell suspension, and the suspension was centrifuged through a $4.0 \%$ bovine serum albumin (BSA) solution for $5 \mathrm{~min}$ at $1000 \mathrm{rpm}$. The pelleted cells were resuspended in Eagle's MEM supplemented with 1.0 $\mathrm{mm}$ glutamine, $33 \mathrm{~mm}$ glucose, $10 \%$ fetal calf serum, and $180 \mu \mathrm{M}$ gentamycin.

The primary astrocytes were plated in $150 \mathrm{~cm}^{2}$ culture flasks and purified. Briefly, the cells were incubated at $37^{\circ} \mathrm{C}$ in a humidified environment containing $5.0 \% \mathrm{CO}_{2}$ for $4-6 \mathrm{~d}$. The cultures were shaken at $250 \mathrm{rpm}$ for $6-18 \mathrm{hr}$ at $37^{\circ} \mathrm{C}$, and the medium was removed. This procedure eliminated the oligodendrocytes from the culture because astrocytes remained attached to the plate, whereas the oligodendrocytes were shaken loose and removed with medium. The result was cultures that contained $>95 \%$ astrocytes, as identified by immunostaining with an anti-glial fibrillary acidic protein antibody. After the cultures were purified, they were grown for an additional 7-10 d in a serum-free medium (equal volumes of MEM and F12 medium with $5.0 \mathrm{mg} / 1$ insulin, $5.0 \mathrm{mg} / \mathrm{l}$ transferrin, and $5.0 \mu \mathrm{g} / 1$ selenium; Collaborative Biomedical, Bedford, MA).

Ethanol was added to the medium of many of the cultures. Ethanol is a volatile liquid. To maintain stable ethanol concentrations in the culture medium, a method using sealed containers was used (Adickes et al., 1988; Pantazis et al., 1992; Luo and Miller, 1997b). Briefly, ethanol was added to the medium, and the culture dishes were placed in a bath containing ethanol in the same concentration as that in the medium. Carbon dioxide was added to the sealed container to maintain the volume of $\mathrm{CO}_{2}$ at $5.0 \%$. Ethanol concentration was assayed using a kit that relies on the conversion of NAD to NADH, which is catalyzed by alcohol dehydrogenase (UV332, Sigma). Using this procedure, we have shown that the ethanol concentration in the culture medium was stable and maintained for $3 \mathrm{~d}$ at $>90 \%$ of the original concentration (Luo and Miller, 1997b).

\section{Cell proliferation assays}

Cell counting. Astrocytes $(60,000 / \mathrm{ml})$ were plated in the wells of $24-w e l l$ culture trays and incubated in a serum-free medium. Twenty-four hours after plating (day 0), growth factor and/or ethanol treatment was initiated. The number of cells was counted in untreated cultures on day 0 and in cultures treated for $3 \mathrm{~d}$ with a PDGF ligand $(0$ or $30 \mathrm{ng} / \mathrm{ml}$; Santa Cruz Biotechnology, Santa Cruz CA) (>97\% purity) and/or ethanol (0, 200, 400 , or $800 \mathrm{mg} / \mathrm{dl}$ ). The medium was carefully removed from the culture well with a Pasteur pipette before counting.

To ensure that no cells remained floating in the medium or were accidentally drawn off, the medium was examined with an inverted light microscope. No floating cells were found, even for cultures treated with high concentrations of ethanol $(800 \mathrm{mg} / \mathrm{dl})$ for $3 \mathrm{~d}$. Thus, the counts of the cells attached to the floor of the well appeared to be accurate measures of total cell number.

Viable and dead/dying cells were distinguished using a trypan blue exclusion assay. Trypan blue was used to identify viable cells, because only living cells can prevent the dye from passing through their cell membranes. After the medium was removed, a solution containing 0.15 $\mathrm{ml}$ of $0.25 \%$ trypsin in $0.10 \%$ EDTA and $0.15 \mathrm{ml}$ of $0.40 \%$ trypan blue in 0.010 м PBS, pH 7.4, was added to the well. The solution was gently triturated to detach the cells. Using this procedure, the cells were simultaneously detached from the floor of the plate and labeled. The numbers of viable (trypan blue-negative) and dead/dying (trypan bluepositive) cells were counted with a hemocytometer. Two tallies per well were taken, and the mean for three wells was used as a data point.

[3H]thymidine incorporation. A second independent assay of cell proliferation was determined by measuring the amount of $\left[{ }^{3} \mathrm{H}\right]$ thymidine $\left(\left[{ }^{3} \mathrm{H}\right] \mathrm{dT}\right)$ incorporated during a $1 \mathrm{hr}$ exposure. Cells were grown for $3 \mathrm{~d}$ in $35 \mathrm{~mm}$ Petri dishes that contained $2.0 \mathrm{ml}$ of serum-free culture medium. The medium contained one of the two PDGF ligands ( 0 or 30 $\mathrm{ng} / \mathrm{ml})$ and/or ethanol (0 or $400 \mathrm{mg} / \mathrm{dl})$. Thus, there were six treatment groups: (1) untreated cells, (2) cells treated with ethanol alone, (3) cells treated with PDGF-AA alone, (4) cells treated with PDGF-BB alone, (5) cells treated with PDGF-AA and ethanol, and (6) cells treated with PDGF-BB and ethanol.

After $3 \mathrm{~d}$ of PDGF and/or ethanol treatment, $10 \mu \mathrm{l}$ of $\left[{ }^{3} \mathrm{H}\right] \mathrm{dT}$ (New England Nuclear, Boston MA; specific activity $\sim 80 \mathrm{Ci} / \mathrm{mmol}$ ) was added to a culture dish. One hour later, the radioactive medium was removed. Cells were detached from the dish by adding $0.30 \mathrm{ml}$ of a solution containing $0.25 \%$ trypsin and $0.10 \%$ EDTA. The cells were mixed and incubated with $4.0 \mathrm{ml}$ of $10 \%$ ice-cold trichloroacetic acid (TCA) in PBS for $20 \mathrm{~min}$. TCA-lysed cells were poured into a Millipore chimney with a Whatman GF/A glass-fiber filter. The precipitated DNA remained on the filter, and to ensure a quantitative recovery and to reduce background, the filter was washed three times with fresh, cold 5.0\% TCA. The filter was dried with $95 \%$ ethanol and placed into a scintillation vial containing $15 \mathrm{ml}$ of a scintillation cocktail (DuPont NEN, Boston, MA). The amount of $\left[{ }^{3} \mathrm{H}\right]$ incorporated in the samples was counted with a model LS3801 scintillation counter (Beckman, Brea, CA).

\section{Signal transduction}

Receptor autophosphorylation. The activation of a receptor kinase is one of the initial steps in PDGF-mediated signal transduction. An index of receptor kinase activity is ligand-triggered receptor autophosphorylation. PDGF is mitogenic for various neural cells (Valenzuela et al., 1997), whereas ethanol is a potent anti-proliferative agent (Miller, 1992; Luo and Miller, 1998). In fact, ethanol can antagonize PDGF-mediated cell proliferation in various neuroblastoma cells (Luo and Miller, 1997a,b). It is critical to know whether ethanol alters PDGF-mediated receptor phosphorylation.

Astrocytes were prepared for receptor phosphorylation studies by growing them to $80-90 \%$ confluency in $60 \mathrm{~mm}$ dishes in a medium containing $10 \%$ serum. The medium was removed, and the cells were washed twice with a serum-free medium and then maintained in the serum-free medium for $24 \mathrm{hr}$. After serum starvation, the cells were treated with $30 \mathrm{ng} / \mathrm{ml}$ of either PDGF-AA or PDGF-BB (Santa Cruz Biotechnology) for 5, 10, 20, 40, or $60 \mathrm{~min}$, and the medium was removed. Cells were washed twice with cold PBS, then incubated in $0.50 \mathrm{ml}$ of RIPA buffer at $4^{\circ} \mathrm{C}$ for $10 \mathrm{~min}$. Cells were removed by scraping them from the dish, transferred to $1.5 \mathrm{ml}$ Eppendorf tubes, and spun at $10,000 \times g$ at $4^{\circ} \mathrm{C}$ for $15 \mathrm{~min}$.

Receptor immunoprecipitates were generated as follows. The cell lysate was collected, and an aliquot containing $200 \mu \mathrm{g}$ of protein was incubated with a rabbit polyclonal antibody against either PDGF $\alpha \mathrm{r}$ or PDGF $\beta$ r (1:50 in PBS) for $1.0 \mathrm{hr}$ at $4^{\circ} \mathrm{C}$. Twenty microliters of Protein A/G conjugated to agarose (Santa Cruz Biotechnology) was added to the lysate, and the mixture was incubated overnight at $4^{\circ} \mathrm{C}$. Immunoprecipitates were collected by centrifugation at $10,000 \times g$ for $10 \mathrm{~min}$ at $4^{\circ} \mathrm{C}$. The pellet was washed three times with $0.50 \mathrm{ml}$ RIPA buffer. After a final wash, the supernatant was aspirated. The pellet was resuspended in $20 \mu \mathrm{l}$ of electrophoresis sample buffer, and the suspension was boiled for $5 \mathrm{~min}$.

The samples were electrophoretically separated and transferred to nitrocellulose membranes for immunoblotting. Nonspecific binding was blocked by washing the filter with $5.0 \%$ BSA in PBS and $0.10 \%$ Tween-20 (TPBS). The filters were probed with a monoclonal antibody against phosphorylated tyrosine (PY20; 1:20,000 in PBS; Transduction Laboratories, Lexington KY). The immunocomplexes were detected with the enhanced chemiluminescence (ECL) method. To assure that alterations in receptor tyrosine phosphorylation did not result from variations in receptor content, the nitrocellulose membranes were stripped of the 
PY20 antibody and reprobed with an anti-receptor subunit antibody. For stripping, nitrocellulose membranes were submerged in a solution of 100 $\mathrm{mm} \beta$-mercaptoethanol, 2.0\% SDS, $62.5 \mathrm{~mm}$ Tris-HCl, $\mathrm{pH}$ 6.7, for $30 \mathrm{~min}$ at $50^{\circ} \mathrm{C}$ or overnight at $4^{\circ} \mathrm{C}$. After being stripped, a membrane was washed with TPBS, blocked with $5.0 \%$ milk, and reprocessed with either an anti-PDGF $\alpha \mathrm{r}$ or an anti-PDGF $\beta \mathrm{r}$ antibody.

Association of Ras-GAP. The phosphorylated receptor binds to an $\mathrm{SH} 2$ domain effector molecule, e.g., Ras-GAP, that in turn feeds into the Ras-Raf-MAPK pathway. Therefore, the effects of PDGF and ethanol on the binding of a PDGF receptor with Ras-GAP was examined. Astrocytes were maintained in a serum-free medium for $24 \mathrm{hr}$ and then treated with PDGF-AA or PDGF-BB $(30 \mathrm{ng} / \mathrm{ml})$ for $10 \mathrm{~min}$. The cells were lysed with a lysis buffer $(1.0 \%$ Triton X-100, $150 \mathrm{~mm} \mathrm{NaCl}, 10 \mathrm{~mm}$ Tris, $\mathrm{pH}$ 7.4, 1.0 mм EDTA, $1.0 \mathrm{~mm}$ EGTA, $0.20 \mathrm{~mm}$ sodium vanadate, $0.20 \mathrm{~mm}$ PMSF, and $0.50 \%$ Nonidet P-40). Cell lysates were centrifuged at $10,000 \times g$ for $10 \mathrm{~min}$, and supernatants were collected. The solubilized protein in the supernatant $(200 \mu \mathrm{g})$ was immunoprecipitated with either an anti-PDGF $\alpha$ r or an anti-PDGF $\beta$ r antibody. Ras-GAP associated with PDGF receptors was co-immunoprecipitated. Immunocomplexes were electrophoretically separated on $10.0 \%$ polyacrylamide gel and transferred to nitrocellulose membranes by the method described above. The nitrocellulose membranes were probed with monoclonal antibody directed against Ras-GAP (1:800 dilution; Transduction Laboratories).

MAPK activity. MAPK is considered to be a gateway of mitogenic activity. Therefore, the activity of this kinase was examined in nearconfluent cultures of purified cortical astrocytes. Astrocytes were grown in a serum-free medium for $24 \mathrm{hr}$ and then treated with ethanol (400 $\mathrm{mg} / \mathrm{dl}$ ) and/or a PKC inhibitor, 1-(5-isoquino-linesulfonyl)-2methypiperazine (H-7; $50 \mu \mathrm{M}$; Calbiochem, San Diego, CA). At this concentration, $\mathrm{H}-7$ specifically affects the activity of all PKC isoforms without altering the activity of other enzymes such as receptor kinases (Hidaka et al., 1984; Choudhury et al., 1993). One hour after ethanol and/or H-7 treatment, the cultures were incubated with a growth factor (PDGF-AA or PDGF-BB; $30 \mathrm{ng} / \mathrm{ml}$ ) for $5,10,20,60$, or $90 \mathrm{~min}$. After growth-factor stimulation, the cells were rinsed three times with ice-cold PBS $(0.01 \mathrm{M})$ and solubilized with $0.30 \mathrm{ml}$ lysis buffer $(50 \mathrm{~mm}$ $\beta$-glycerophosphate, $\mathrm{pH} 7.2), 100 \mathrm{~mm}$ sodium vanadate, $5.0 \mathrm{~mm}$ magnesium chloride, $1.0 \mathrm{~mm}$ EGTA, $0.50 \%$ Triton X-100, $1.0 \mathrm{~mm}$ 1,4dithiothreitol, $3.0 \%$ aprotinin, and $10 \mu \mathrm{g} / \mathrm{ml}$ leupeptin) at $4^{\circ} \mathrm{C}$ for $20 \mathrm{~min}$. Cell lysates were collected and centrifuged at $10,000 \times g$ for $10 \mathrm{~min}$. Cellular proteins $(600 \mu \mathrm{g})$ in the supernatants were used for immunoprecipitating MAPK. MAPK was immunoprecipitated with an antibody directed against extracellular signal-regulated kinase (ERK) (1:50 dilution; Transduction Laboratories), which recognizes both the $44 \mathrm{kDa}$ and $42 \mathrm{kDa}$ ERKs. MAPK activity in the immunoprecipitates was assayed by the phosphorylation of myelin basic protein (MBP) using a commercial kit (Upstate Biotechnology, Lake Placid, NY). MAPK-mediated transfer of the $\gamma$-phosphate of $\left[\gamma_{-}^{-32} \mathrm{P}\right] \mathrm{ATP}$ to MBP was quantified with a scintillation counter. The experiment was replicated four times.

$P K C$ activity. PKC is a key component of receptor-initiated activities. Ethanol is known to alter PKC activity (Messing et al., 1991; DePetrillo and Liou, 1993; Roivainen et al., 1995). Therefore, the effects of ethanol on growth factor-mediated changes in PKC activity were explored.

Cultured astrocytes were grown in a serum-free medium for $24 \mathrm{hr}$, treated with ethanol $(0$ or $400 \mathrm{mg} / \mathrm{dl})$ for $1 \mathrm{hr}$, and then exposed to either PDGF-AA or PDGF-BB $(30 \mathrm{mg} / \mathrm{dl})$ for $10 \mathrm{~min}$. The cells were washed in PBS and solubilized with $0.30 \mathrm{ml}$ lysis buffer, and cell lysates were collected. Cell lysates containing $600 \mu \mathrm{g}$ protein were chilled, sonicated for $30 \mathrm{sec}$, and centrifuged at $100,000 \times g$ for $30 \mathrm{~min}$ at $4^{\circ} \mathrm{C}$. The supernatants and pellets were processed separately for cytosolic and membranal PKC activity, respectively. This step was necessary because activation by growth factors induces PKC to translocate from the cytosol to the plasma membrane (Nishizuka, 1992; Inui et al., 1994). Additional steps were required to prepare the pellets. They were solubilized with 40 $\mu \mathrm{l}$ of the lysis buffer described above except that the concentration of Triton X-100 was increased to $1.0 \%$, and then centrifuged at $14,000 \times g$ for $10 \mathrm{~min}$ at $4^{\circ} \mathrm{C}$. This new supernatant was used in our assay of PKC activity in the cell membranes.

The phosphotransferase activity of PKC of the cytosolic and membranal fractions was measured with a commercial kit (Upstate Biotechnology). This assay was based on the PKC-mediated transfer of the $\gamma$-phosphate of $\left[\gamma^{32} \mathrm{P}\right]$ ATP to a specific substrate peptide (OKRPSQRSKYL). In some cases, H-7 (50 $\mu \mathrm{M})$ was applied to block PKC activity. H-7 did not affect the autophosphorylation of PDGF receptors
(Choudhury et al., 1993). As a negative control, PKC activity was blocked by pretreating the cells for $1 \mathrm{hr}$ with $\mathrm{H}-7$ before performing the PKC activity assay.

\section{Ligand and receptor expression}

Immunoblots. Although the other parts of this investigation examined the acute effects of ethanol on signal transduction, it was important to determine whether ethanol had more lasting effects on the upstream effectors: the PDGF ligands and their receptors. The expression of these proteins was determined using Western immunoblots.

Primary astrocytes were grown with a serum-free medium in $60 \mathrm{~mm}$ culture dishes. The cells were treated with ethanol $(0,200,400$, or 800 $\mathrm{mg} / \mathrm{dl}$ ) for $3 \mathrm{~d}$. The medium was removed, and the cells were washed twice with ice-cold PBS. The cells were lysed by a 10 min wash in $1.0 \mathrm{ml}$ ice-cold RIPA buffer (150 mM NaCl, $50 \mathrm{~mm}$ Tris, $\mathrm{pH}$ 8.0, 1.0\% Nonidet P-40, $0.10 \%$ SDS, $0.50 \%$ deoxycholic acid sodium, $0.10 \mathrm{mg} / \mathrm{ml}$ phenymethylsulfonyl fluoride, $1.0 \mathrm{~mm}$ sodium orthovanadate, $10.0 \mu \mathrm{g} / \mathrm{ml} \mathrm{leu}$ peptin, $2.0 \mu \mathrm{g} / \mathrm{ml}$ pepstatin $\mathrm{A}$, and $3.0 \%$ aprotinin). Lysates were centrifuged at $10,000 \times g$ for $15 \mathrm{~min}$. The supernatants, which contained cellular proteins, were collected, and the protein concentration of each sample was determined (Lowry et al., 1951). Proteins were mixed in an equal volume of electrophoresis sample buffer $(1.0 \mathrm{ml}$ glycerol, $0.50 \mathrm{ml}$ $\beta$-mercaptoethanol, $3.0 \mathrm{ml} \mathrm{10 \%} \mathrm{SDS,} 1.25 \mathrm{ml} \mathrm{1.0} \mathrm{M} \mathrm{Tris-HCl,} \mathrm{pH} \mathrm{6.7,} \mathrm{and}$ $2.0 \mathrm{mg}$ bromophenol blue) and boiled for $3 \mathrm{~min}$. For comparison, some samples were not heated. The amount of expression and the size of the bands were apparently unaffected by boiling.

The proteins were separated by gel electrophoresis. Thirty micrograms of protein were loaded on each lane of an SDS-polyacrylamide gel $(10 \%$ acrylamide) and electrophoresed. After being separated, the samples were transferred to $0.20 \mu \mathrm{m}$ nitrocellulose filters. Nonspecific antigenicity was blocked by washing the filters for $1 \mathrm{hr}$ at room temperature with TPBS. After two washes (10 min each) with TPBS, the filters were then incubated for $1 \mathrm{hr}$ at room temperature with a polyclonal antibody directed against PDGF A-chain, PDGF B-chain, PDGF $\alpha$, or PDGF $\beta r$ (diluted 1:500, Santa Cruz Biotechnology). Subsequently, the filters were washed in TPBS and incubated with a secondary antibody conjugated to horseradish peroxidase (1:2000 dilution; Amersham, Arlington Heights IL). The immunocomplexes were detected with an ECL method (Amersham). Three replicate immunoblots were processed for each primary antibody.

Two controls for nonspecific immunoreactivity were performed. In these trials, filters were processed without the primary or secondary antibody. The results of the controls were consistently negative.

Scatchard analysis. The effects of ethanol on the numbers of PDGF-AA and PDGF-BB binding sites were determined using a Scatchard saturation binding assay (Seifert et al., 1993). This study complements the receptor expression study described above. Although the immunoblotting study provides data on the total expression of PDGF receptors (membrane-bound as well as cytosolic pools), the saturation binding assay generates information only on the extracellularly directed membrane-bound receptors. Thus, the data from the Scatchard and immunoblotting analyses can be used to determine the effects of ethanol on the translocation of the receptors. Furthermore, the Scatchard analysis provides valuable data on the ligand-binding affinities.

Astrocytes were raised in 24-well culture trays containing a medium supplemented with $10 \%$ fetal calf serum and ethanol $(0$ or $400 \mathrm{mg} / \mathrm{dl})$ for $3 \mathrm{~d}$. The cells were rinsed twice with cold binding buffer (Ham's F-12, 25 mM HEPES, pH 7.4, and $0.25 \%$ BSA). $\left[{ }^{125} \mathrm{I}\right]$ PDGF-AA or $\left[{ }^{125} \mathrm{I}\right] \mathrm{PDGF}-$ $\mathrm{BB}$ (specific activities $76 \mathrm{cpm} / \mathrm{pg}$ and $220 \mathrm{cpm} / \mathrm{pg}$, respectively; iodinated at the Iowa City Veterans Affairs Diabetes Research Center) was added to wells at one of a range of concentrations $(0.625-20 \mathrm{ng} / \mathrm{ml})$ in $0.20 \mathrm{ml}$ binding buffer. The cells were incubated for $3.5 \mathrm{hr}$ at $4^{\circ} \mathrm{C}$. The radioactive binding buffer was removed, and the cells were washed three times with fresh, cold binding buffer. Cells were extracted by the addition of PBS containing $1.0 \%$ Triton X-100 and $0.25 \%$ BSA, and cell-associated radioactivity (bound ligands) was quantified using an Auto-Gamma 5000 gamma counter (Packard, Downers Grove, IL).

The amounts of bound $\left[{ }^{125} \mathrm{I}\right]$ ligand and free $\left[{ }^{125} \mathrm{I}\right]$ ligand were determined. The concentration of free PDGF was calculated by subtracting the amount of PDGF bound to the cells from the amount of $\left[{ }^{125} \mathrm{I}\right] \mathrm{PDGF}$ originally added to the wells. Nonspecific binding was determined by preincubation with $200 \mathrm{ng} / \mathrm{ml}$ of unlabeled ligands. Nonspecific binding ranged from 10 to $15 \%$ of the total binding. Specific binding for PDGF receptors was determined by subtracting nonspecific binding from total binding. The Scatchard plot (the amount of bound $\left[{ }^{125} \mathrm{I}\right]$ ligand vs the 


\section{DAY 0}

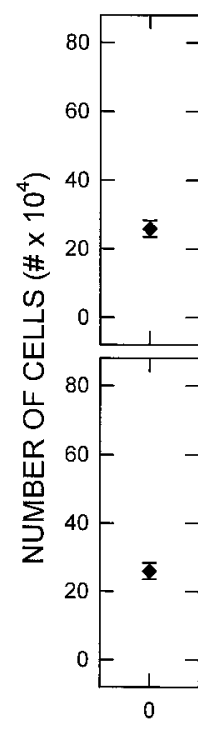

DAY 3

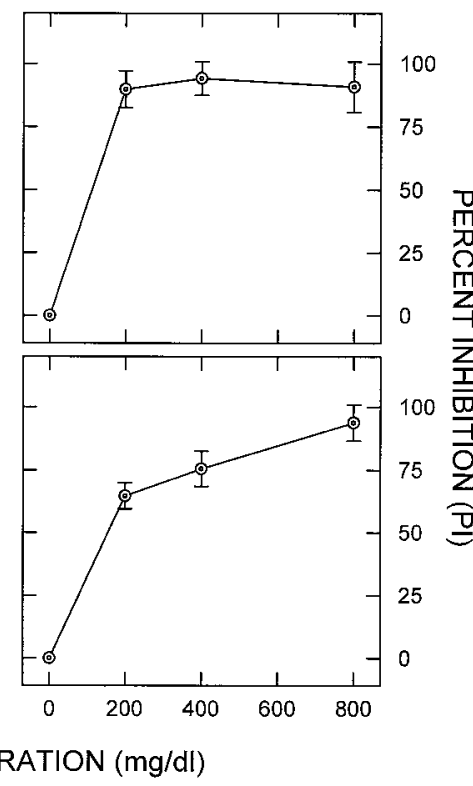

Figure 1. PDGF-mediated astrocyte growth. Astrocytes were maintained in a serum-free medium and treated with either PDGF-AA or PDGF-BB $(30 \mathrm{ng} / \mathrm{ml})$ for $3 \mathrm{~d}$. The left panel shows the mean number of cells in a culture ( \pm SEM) before PDGF or ethanol $(200-800 \mathrm{mg} / \mathrm{dl})$ was added. The plot depicts the original (concocted) ethanol concentrations. The middle panel describes the number of cells in a culture after $3 \mathrm{~d}$ of treatment with PDGF and/or ethanol. The amount of ethanol-induced inhibition (expressed as a percentage) was measured against the amount of PDGF stimulation in the absence of ethanol (right panel). The formula for calculating the percent inhibition $(P I)$ is $P I=\left[(\mathrm{PDGF}+)_{0}-(\mathrm{PDGF}+)_{\mathrm{x}}\right] /\left[(\mathrm{PDGF}+)_{0}-(\mathrm{PDGF}-)_{\mathrm{x}}\right]$ $(100 \%)$, in which (PDGF +$)$ and $(\mathrm{PDGF}-)$ are the numbers of cells in cultures treated with and without PDGF, respectively, after being treated with a particular concentration of ethanol (i.e., 0 or $\mathrm{x} \mathrm{mg/dl).} \mathrm{Each} \mathrm{data} \mathrm{point} \mathrm{is} \mathrm{based} \mathrm{on} \mathrm{six}$ trials. ratio of the concentration of bound $\left[{ }^{125} \mathrm{I}\right]$ ligand to the amount of free $\left[{ }^{125}\right.$ I]ligand) was drawn. The number of binding sites $\left(B_{\max }\right)$ and the receptor affinity $\left(K_{\mathrm{d}}\right)$ were calculated (Rosenthal, 1967) using the software LIGAND (Munson and Rodbard, 1980). Cells in parallel wells that were not treated with a radiolabeled ligand were harvested, and the number of viable cells was determined (see above). These numbers were used to calculate the number of binding sites per cell. All data points were based on quadruplicate samples.

\section{Statistical analysis}

Differences among the treatment groups (e.g., growth factor- or ethanoltreated) were examined by two-way ANOVA. Student-Newman-Keuls tests were used for post hoc comparisons. Tukey B tests were used to examine changes over time. Statistical analyses were performed using the software Sigmastat 2.0 (Jandel, San Rafael, CA).

\section{RESULTS}

\section{PDGF-mediated cell proliferation}

Astrocytes did not grow in a nonsupplemented, serum-free medium. That is, the number of cells in the untreated cultures did not change significantly over a $3 \mathrm{~d}$ experiment.

PDGF ligands were potent mitogens for astrocytes. After the addition of PDGF-AA or PDGF-BB $(30 \mathrm{ng} / \mathrm{ml})$, the number of astrocytes increased significantly $(p<0.05)$ (Fig. 1). The stimulatory effect of PDGF-BB was greater than that for PDGF-AA. After $3 \mathrm{~d}$ treatment, PDGF-AA and PDGF-BB increased the number of cells over controls by 1.5- and 2.4-fold, respectively. The mitogenic effects of the PDGF ligands were further assessed by measuring PDGF-stimulated $\left[{ }^{3} \mathrm{H}\right] \mathrm{dT}$ incorporation (Fig. 2). As with the changes in cell number, both PDGF-AA and PDGF-BB treatment significantly $(p<0.05)$ increased $\left[{ }^{3} \mathrm{H}\right] \mathrm{dT}$ uptake, and PDGF-BB had a stronger stimulatory effect.

Cell survival (as indicated by the incidence of trypan bluepositive cells) was not affected by either PDGF ligand. The incidence of astrocyte death was between $6.6 \pm 0.9$ and $7.9 \pm$ $1.3 \%$ in the control and growth-factor treated cultures. No statistically significant differences were detected. Therefore, the changes in cell number and $\left[{ }^{3} \mathrm{H}\right] \mathrm{dT}$ incorporation can be attributed solely to the effects of growth factors on the cell proliferation.

Ethanol treatment attenuated PDGF-mediated growth in a

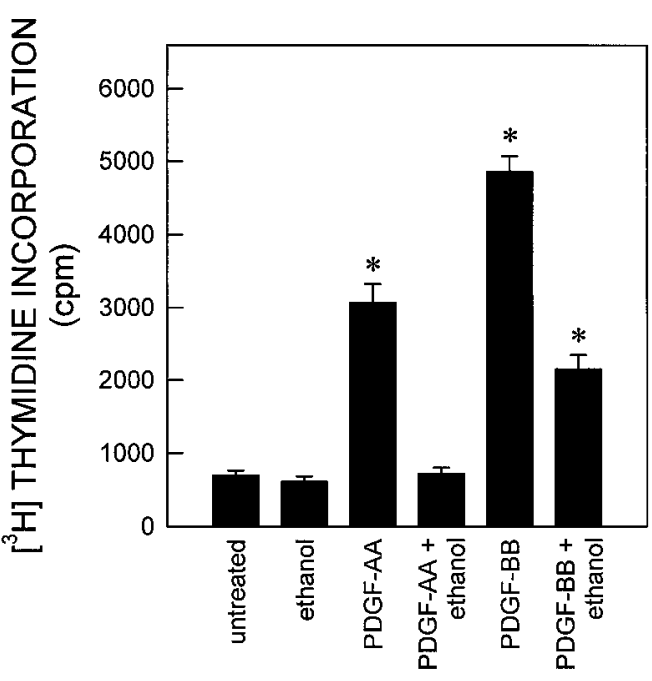

TREATMENT

Figure 2. Effects of PDGF and ethanol on $\left[{ }^{3} \mathrm{H}\right] \mathrm{dT}$ incorporation. Astrocytes were maintained in a serum-free medium. $\left[{ }^{3} \mathrm{H}\right] \mathrm{dT}$ incorporation was measured after $3 \mathrm{~d}$ of treatment with PDGF (0 or $30 \mathrm{ng} / \mathrm{ml}$ ) and/or ethanol $(0$ or $400 \mathrm{mg} / \mathrm{dl})$. Data represent the means $( \pm \mathrm{SEM})$ for four independent experiments. Asterisks denote statistically significant differences $(p<0.05)$ in comparisons with the untreated (control) cultures.

concentration-dependent manner (Fig. 1). Furthermore, ethanol differentially affected the action of PDGF-AA and PDGF-BB. At concentrations of $200 \mathrm{mg} / \mathrm{dl}$ or higher, ethanol completely blocked PDGF-AA-mediated cell growth, but at $200 \mathrm{mg} / \mathrm{dl}$, ethanol only partially $(65 \%)$ inhibited a PDGF-BB-mediated increase in cell number. The inhibitory effect of ethanol on cell proliferation was confirmed in a study of PDGF-affected $\left[{ }^{3} \mathrm{H}\right] \mathrm{dT}$ uptake. Ethanol $(400 \mathrm{mg} / \mathrm{dl})$ completely blocked PDGF-AAmediated $\left[{ }^{3} \mathrm{H}\right] \mathrm{dT}$ uptake and partially attenuated PDGF-BBstimulated $\left[{ }^{3} \mathrm{H}\right] \mathrm{dT}$ incorporation (Fig. 2). Cell death apparently was not affected by treatment with ethanol or ethanol and a growth factor. The numbers of dead/dying (trypan blue-positive) 


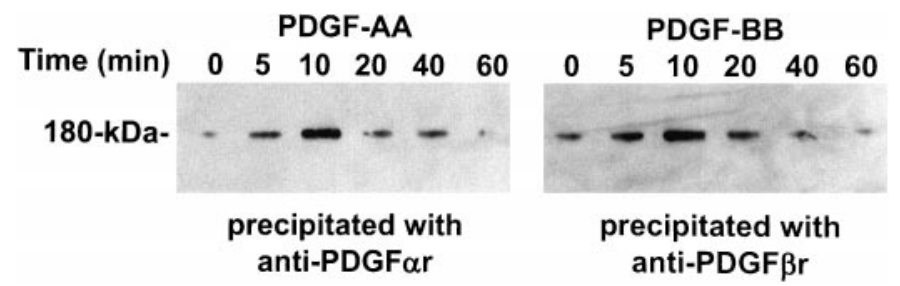

Figure 3. Time sequence of PDGF receptor autophosphorylation. Glia were isolated from cortices of 5-d-old rats, purified, and cultured in serum-supplemented medium for 2 weeks. Subsequently, the cells were grown in a serum-free medium for $24 \mathrm{hr}$ and treated with PDGF-AA or PDGF-BB for $0,5,10,20,40$, or $60 \mathrm{~min}$. PDGF $\alpha$ r and PDGF $\beta \mathrm{r}$ were immunoprecipitated separately and assayed for tyrosine phosphorylation. The experiment was repeated three times.

cells in these cultures were not significantly different from the numbers in the untreated cultures. The frequency of trypan blue-positive neurons was $7.6 \pm 1.3$ to $9.2 \pm 1.6 \%$.

\section{Receptor autophosphorylation}

PDGF receptors are tyrosine kinases. When they bind a ligand, these kinases autophosphorylate and set a cascade of events into motion. The tyrosine phosphorylation of a specific receptor subunit was determined by an immunoprecipitation procedure.

Receptor activation was a fast process (Fig. 3); increased receptor autophosphorylation was detected within 5 min of adding the PDGF. It peaked at 10 min after growth factor administration and then declined. PDGF-AA-stimulated phosphorylation was detected only in samples immunoprecipitated with an antiPDGF $\alpha \mathrm{r}$ antibody (Fig. 4). This indicates that PDGF-AA induced the phosphorylation of only the PDGF $\alpha \mathrm{r}$ and not the PDGF $\beta$ r. On the other hand, PDGF-BB induced the phosphorylation of samples immunoprecipitated with either an antiPDGF $\alpha$ r or an anti-PDGF $\beta r$ antibody. Thus, PDGF-BB induced the phosphorylation of both receptor subtypes.

In the presence of ethanol $(400 \mathrm{mg} / \mathrm{dl})$, both PDGF-AA- and PDGF-BB-mediated phosphorylation of the PDGF $\alpha \mathrm{r}$ was re- duced; however, PDGF-BB-stimulated phosphorylation of PDGF $\beta \mathrm{r}$ was not affected. Therefore, ethanol inhibited only the tyrosine phosphorylation of the PDGF $\alpha$ r.

\section{Association of Ras-GAP}

Activated tyrosine kinase receptors bind to downstream effectors with an SH2 domain. One such effector is Ras-GAP. PDGF-AA induced the association of Ras-GAP to PDGF $\alpha$, whereas PDGF-BB resulted in Ras-GAP binding to either receptor isoform (Fig. 5). Ethanol exposure (1 hr) significantly inhibited both PDGF-AA- and PDGF-BB-mediated association of Ras-GAP to PDGF $\alpha$ r, but it had little effect on the binding between Ras-GAP and PDGF $\beta$ r.

\section{MAPK activity}

Both PDGF-AA (30 ng/ml) and PDGF-BB (30 ng/ml) rapidly and transiently stimulated MAPK activity (Fig. 6). Significant $(p<0.05)$ stimulation appeared within $5 \mathrm{~min}$, was maximal after $10 \mathrm{~min}$, and fell to control levels within $60 \mathrm{~min}$. Of the two ligands, PDGF-BB had a stronger stimulatory effect on MAPK activity. After $10 \mathrm{~min}$ of treatment, PDGF-BB and PDGF-AA increased MAPK activity by 357 and $165 \%$, respectively.

Ethanol treatment $(400 \mathrm{mg} / \mathrm{dl})$ significantly $(p<0.05)$ increased basal MAPK activity (i.e., the activity induced in the absence of growth factors) by $74.0 \%$. Ethanol also affected PDGF-mediated MAPK activity. In the presence of ethanol, PDGF-AA and PDGF-BB (10 min) significantly $(p<0.05)$ increased MAPK activity 219 and $482 \%$, respectively, beyond the amount of MAPK activity in the untreated controls. The ethanolinduced potentiation abated within 20 min after the growth factor was added. This abatement was complete for the cultures treated with PDGF-AA; however, it was incomplete for the cultures treated with PDGF-BB. In the latter, MAPK activity was $51.9 \%$ higher after $90 \mathrm{~min}$ of PDGF stimulation than it was at the beginning of the experiment. Nevertheless, for both PDGF ligands, the amount of activation was maintained at a level signif-
Figure 4. Effect of ethanol on PDGF receptor autophosphorylation. Top, Astrocytes were maintained in a serum-free medium for $24 \mathrm{hr}$, then exposed to ethanol (0 or $400 \mathrm{mg} / \mathrm{dl}$ ) for $1 \mathrm{hr}$. Subsequently, the cells were treated with PDGF-AA or PDGF-BB $(30 \mathrm{ng} / \mathrm{ml})$ in the presence or absence of ethanol for $10 \mathrm{~min}$. Cell lysates were collected, and an equal amount of cellular protein $(200 \mu \mathrm{g})$ was immunoprecipitated with an anti-PDGF $\alpha \mathrm{r}$ or antiPDGF $\beta \mathrm{r}$ antibody. The immunoprecipitates were electrophoretically separated and probed with an antibody (PY2O) directed against phosphorylated tyrosine. Bottom, After the nitrocellulose papers were stripped, they were reprobed with either anti-PDGF $\alpha \mathrm{r}$ or anti-PDGF $\beta \mathrm{r}$ antibody. These blots show that not only did the phosphorylation signal align with the receptor signal, but the loading of the protein on each lane was consistent. Note that protein expression of the PDGF $\alpha \mathrm{r}$ was unaffected by $1 \mathrm{hr}$ ethanol treatment; changes in the expression of the protein PDGF $\alpha$ r required a chronic exposure, e.g., 3 d (Fig. 8). Three repeats of the experiment were performed.
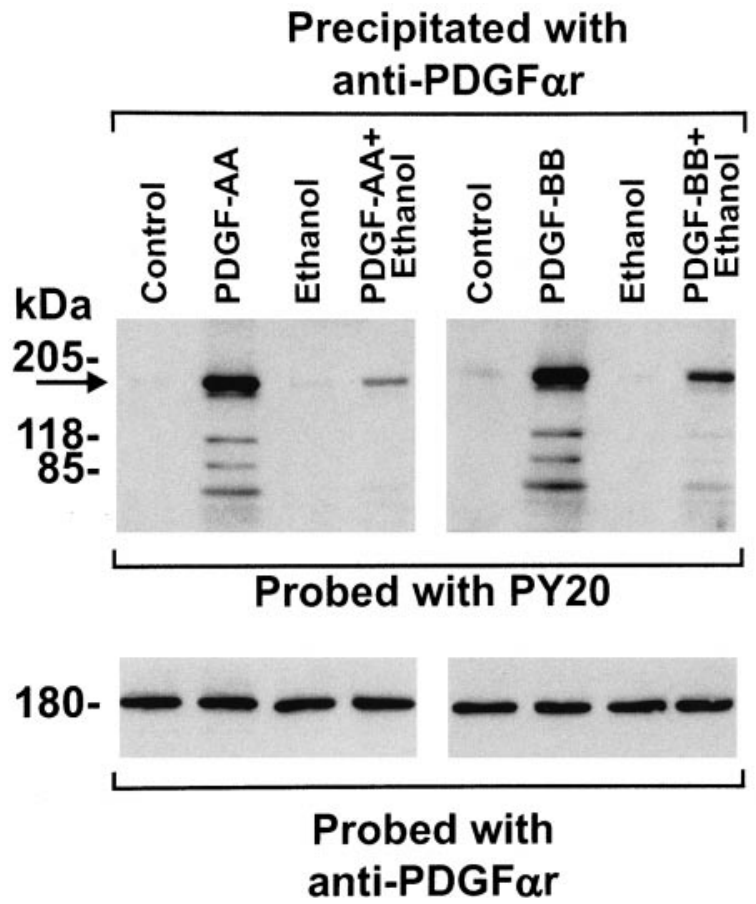

\section{Precipitated with anti-PDGF $\beta r$}
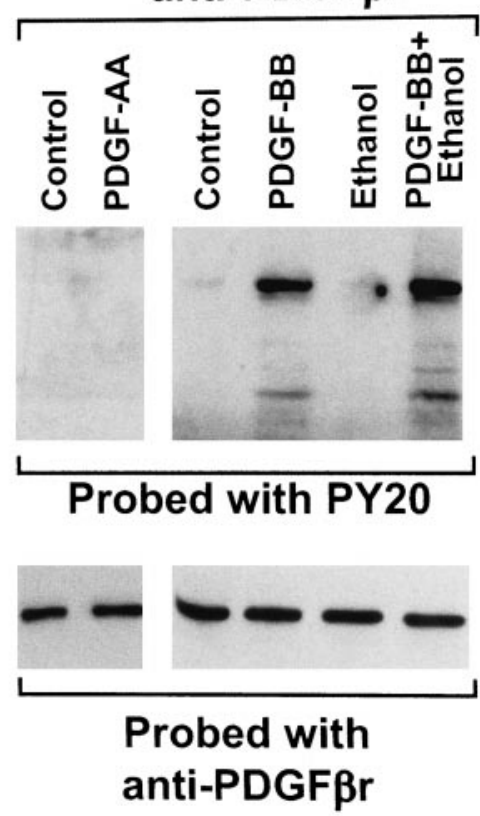


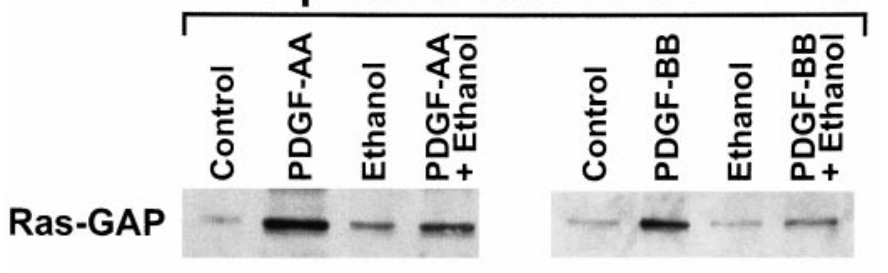

Precipitated with anti-PDGF $\beta \mathrm{r}$

Ras-GAP

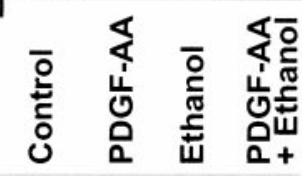

\section{Precipitated with anti-PDGF $\alpha \mathrm{r}$}

\section{Expression of PDGF ligands and receptors}

The expression of PDGF ligands and receptors was examined in cells raised in a serum-free medium using Western immunoblots. Cultured astrocytes expressed both ligand isoforms (Fig. 8). Chronic exposure ( $3 \mathrm{~d}$ ) to ethanol (up to $800 \mathrm{mg} / \mathrm{dl}$ ) did not affect the expression of either ligand. The astrocytes also expressed both receptor subunits. The expression of PDGF $\alpha \mathrm{r}$ was upregulated by ethanol in a concentration-dependent manner; however, the expression of PDGF $\beta \mathrm{r}$ was not affected by ethanol. Note that similar data were obtained for cells raised in a medium containing $10 \%$ fetal calf serum.

Ethanol-induced alterations in PDGF receptor characteristics were examined with a Scatchard analysis. Ethanol did not alter the binding affinity $\left(K_{\mathrm{d}}\right)$ for either PDGF-AA or PDGF-BB (Fig. 9 , Table 1$)$. On the other hand, ethanol significantly $(p<0.05)$ increased the density of PDGF-AA binding sites by $46 \%$. In contrast, the density of PDGF-BB binding sites was not significantly altered by ethanol. Thus, the results of the PDGF binding study were consistent with those of the immunoblotting studies showing that PDGF $\alpha$ r expression was selectively increased by $3 \mathrm{~d}$ treatment with ethanol.

Figure 5. Association of Ras-GAP. After the isolation, purification, and growth in a medium containing $10 \%$ fetal calf serum, astrocytes were maintained in a serum-free medium for $24 \mathrm{hr}$. The cells were exposed to ethanol (0 or $400 \mathrm{mg} / \mathrm{dl})$ for $1 \mathrm{hr}$ and treated with PDGF-AA or PDGF-BB (30 ng/ml) in the presence or absence of ethanol for $10 \mathrm{~min}$. Cell lysates were collected and immunoprecipitated with an anti-PDGF $\alpha \mathrm{r}$ or anti-PDGF $\beta \mathrm{r}$ antibody. The immunoprecipitates were electrophoretically separated and probed with a monoclonal antibody directed against Ras-GAP. The experiment was performed three times.

icantly $(p<0.05)$ greater than that evident in the control cultures.

The effects of PDGF on MAPK activity were further assessed in astrocytes that were treated with H-7. H-7 had little effect on basal MAPK activity; however, H-7 pretreatment significantly $(p<0.05)$ reduced PDGF-enhanced MAPK activity (from 165 to $100 \%$ for PDGF-AA treatment and from 357 to $225 \%$ for PDGF-BB treatment). It is important to note that neither PDGFAA- nor PDGF-BB-mediated kinase activity was totally eliminated by $\mathrm{H}-7$. That is, regardless of whether the cells were exposed to H-7, the MAPK activity in cells treated with a PDGF ligand remained significantly $(p<0.05)$ greater than in control cells.

H-7 pretreatment completely blocked ethanol-stimulated MAPK activity (Fig. 6, inset). In fact, there was no significant difference in the activity expressed by control and ethanol-treated cells. Likewise, in the presence of $\mathrm{H}-7$, the PDGF-AA-mediated stimulation of MAPK activity was eliminated by ethanol. In contrast, PDGF-BB-regulated MAPK activity was only partially, but significantly $(p<0.05)$, inhibited by ethanol.

\section{PKC activity}

PKC activity in the membranes was significantly $(p<0.05)$ increased by ethanol $(400 \mathrm{mg} / \mathrm{dl})$ and PDGF $(30 \mathrm{ng} / \mathrm{ml})$ treatment (Fig. 7). In contrast, ethanol and PDGF had little effect on PKC activity in the cytosolic fraction. The ratio of PKC activity in membranes to total activity (cytosolic plus membranal) was significantly $(p<0.05)$ increased by ethanol and PDGF.

Ethanol potentiated the growth factor-stimulated PKC activity. That is, PKC activity in the membranes of cells treated with PDGF-AA or PDGF-BB and ethanol was significantly $(p<0.05)$ greater (31.3 and $48.8 \%$, respectively) than it was with a growth factor alone. H-7 pretreatment blocked all ethanol- and growth factor-induced stimulation.

\section{DISCUSSION}

\section{PDGF-mediated cell proliferation}

Astrocytes do not grow in a serum-free medium; however, after supplementation with PDGF, astrocytes do proliferate (as shown by changes in cell number and $\left[{ }^{3} \mathrm{H}\right] \mathrm{dT}$ incorporation). Cell death among astrocytes maintained in a serum-free medium occurs at a low rate, and the incidence of this death is unaffected by either PDGF homodimer. Therefore, we conclude that PDGF acts purely as a mitogen. These findings concur with reports that PDGF is a potent mitogen for cultured astrocytes (Prins et al., 1996; Valenzuela et al., 1997). Interestingly, PDGF-AA is a less effective mitogen than PDGF-BB. Similar differential effects have been described for neuroblastoma cells (Luo and Miller, 1997a,b).

Ethanol inhibits PDGF-mediated proliferation of astrocytes in a concentration-dependent manner; i.e., increasing concentrations of ethanol produce progressively stronger inhibition. Ethanol differentially affects the action of two PDGF ligands. PDGFAA-mediated cell proliferation is more susceptible to the action of ethanol. At a concentration of $200 \mathrm{mg} / \mathrm{dl}$, ethanol completely blocks PDGF-AA-stimulated cell proliferation, but it only partially inhibits PDGF-BB-mediated astrocyte growth. A similar differential effect occurs in neuroblastoma cells (Luo and Miller, 1997a,b). In contrast to the effects of ethanol on cell proliferation, astrocyte survival is not compromised either by ethanol alone or in combination with PDGF. This implies that ethanol acts on the signal transduction system mediating growth factor-stimulated cell proliferation.

\section{PDGF-mediated signal transduction}

Receptor activation

The activities of PDGF receptor tyrosine kinases are essential to the mitogenic properties of the ligands. Blocking the receptor kinases eliminates PDGF-mediated cell proliferation (Kovalenko et al., 1994; Buchdunger et al., 1995). Both our study and one by Zhang and Hutchins (1997) show that PDGF treatment induces receptor phosphorylation in cultured neurons and astrocytes. PDGF-AA induces the phosphorylation of only the PDGF $\alpha \mathrm{r}$, whereas PDGF-BB activates both receptor subtypes. These findings are consistent with data on vascular smooth muscle cells 


\section{PDGF-AA PDGF-BB}

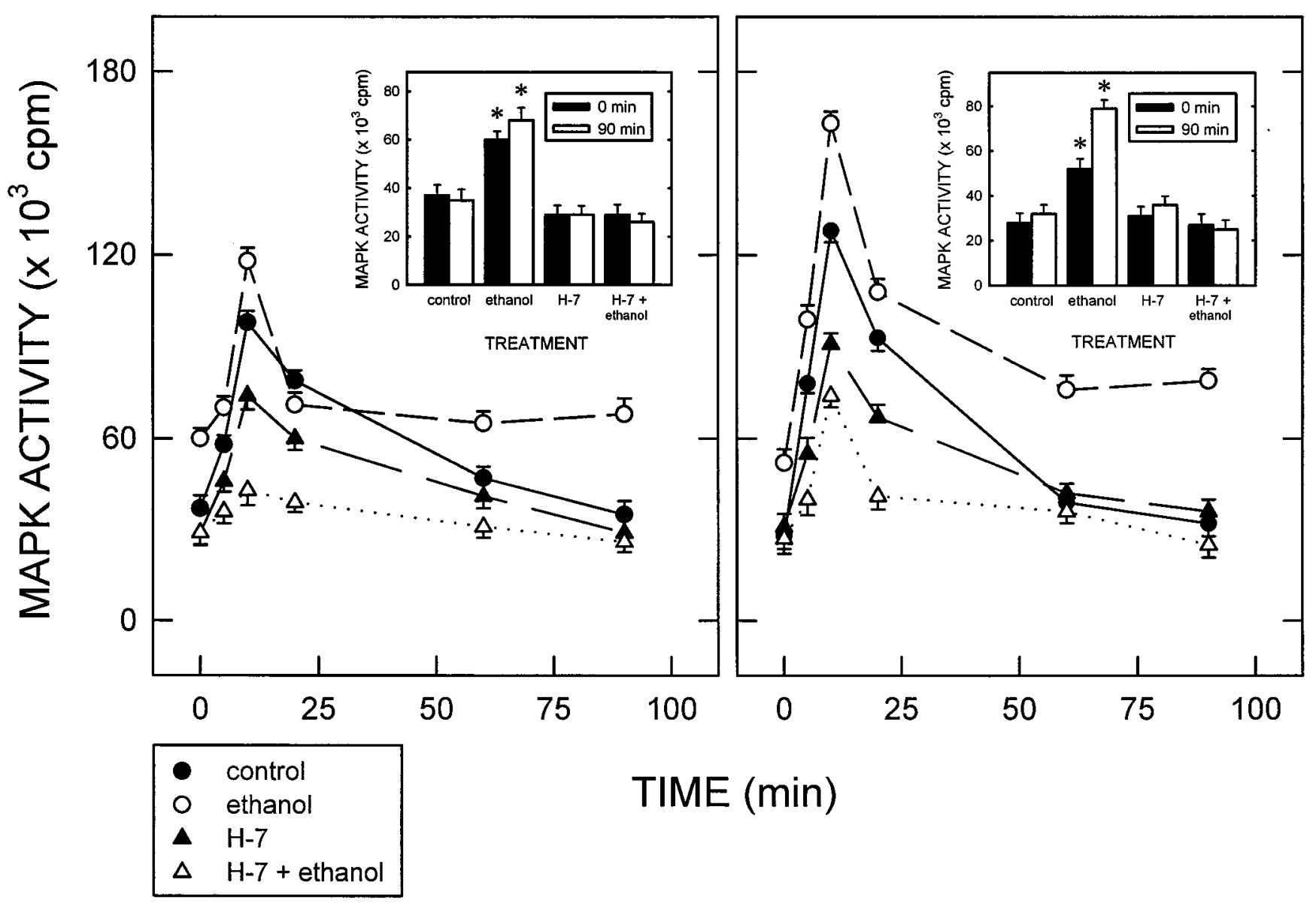

Figure 6. Effects of PDGF, ethanol, and H-7 on time sequence of MAPK activity. MAPK activity was determined for astrocytes pretreated with ethanol $(0$ or $400 \mathrm{mg} / \mathrm{dl})$ and/or H-7 $(0$ or $50 \mu \mathrm{M})$ for $1 \mathrm{hr}$ in a serum-free medium (designated as time 0 min). The cells were then incubated with either PDGF-AA (30 ng/ml) or PDGF-BB (30 ng/ml) for as long as $90 \mathrm{~min}$. Insets, The histograms compare MAPK activity for cultures treated with ethanol $(0$ or $400 \mathrm{mg} / \mathrm{dl})$ and/or $\mathrm{H}-7(0$ or $50 \mu \mathrm{M})$ at time $0 \mathrm{~min}$ (black bars) or at time $90 \mathrm{~min}$ (white bars). Each data point represents the mean of four trials $( \pm \mathrm{SEM})$. Asterisks denote statistically significant $(p<0.05)$ differences relative to the control cultures at time $0 \mathrm{~min}$.

showing the specificity of PDGF-AA for the PDGF $\alpha$ r and the promiscuous ability of PDGF-BB to induce tyrosine phosphorylation of either the PDGF $\alpha$ r or PDGF $\beta r$ (Inui et al., 1994).

\section{Ras-GAP association}

Receptor activation is accompanied by the formation of multimeric complexes between the receptors and downstream SH2containing proteins (Bornfeldt et al., 1995; Hart et al., 1995). The complexes are formed by the binding of phosphorylated tyrosine residues in receptors to the $\mathrm{SH} 2$ domains in the effectors (Fig. 10). This association, in turn, regulates the activity of the effectors. Ras-GAP (an SH2-containing protein) is an important modulator of the Ras-Raf-MAPK signal pathway that eventually results in cell proliferation (Satoh et al., 1993; Zhang et al., 1993; Li et al., 1995).

PDGF-AA induces the association of PDGF $\alpha$ r to Ras-GAP, whereas PDGF-BB recruits Ras-GAP to bind to both PDGF $\alpha$ r and PDGF $\beta$ r. This result is consistent with the finding that PDGF-AA specifically activates the PDGF $\alpha$ r and that PDGF-BB induces the phosphorylation of either the PDGF $\alpha \mathrm{r}$ or the PDGF $\beta$ r. Therefore, downstream receptor signaling by
PDGF-AA and PDGF-BB is mediated solely by the PDGF $\alpha \mathrm{r}$ and by the PDGF $\alpha$ r or PDGF $\beta$, respectively.

\section{MAPK activation}

Activation of the Ras-Raf-MAPK cascade ultimately induces cell proliferation (Bornfeldt et al., 1995) (Fig. 10). Thus, MAPK plays a critical role in the control of cell growth and differentiation. The present study shows that both PDGF-AA and PDGF-BB stimulate MAPK in cultured astrocytes and that PDGF-BB has a stronger effect than PDGF-AA. These data concur with those of Prins et al. (1996).

An alternative pathway to stimulate MAPK activity is through PKC (Sözei et al., 1992; Kolch et al., 1993; Li et al., 1995). The present study shows that pretreatment with $\mathrm{H}-7$ completely blocks PDGF-stimulated PKC activity. Furthermore, both PDGF-AAand PDGF-BB-mediated MAPK activities are partially inhibited by $\mathrm{H}-7$ pretreatment. This incomplete inhibition implies that PDGF can affect MAPK via two pathways: a PKC-dependent and a PKC-independent pathways (Fig. 10). The latter is likely to be the Ras-Raf-MAPK pathway. Dual pathways have been de- 


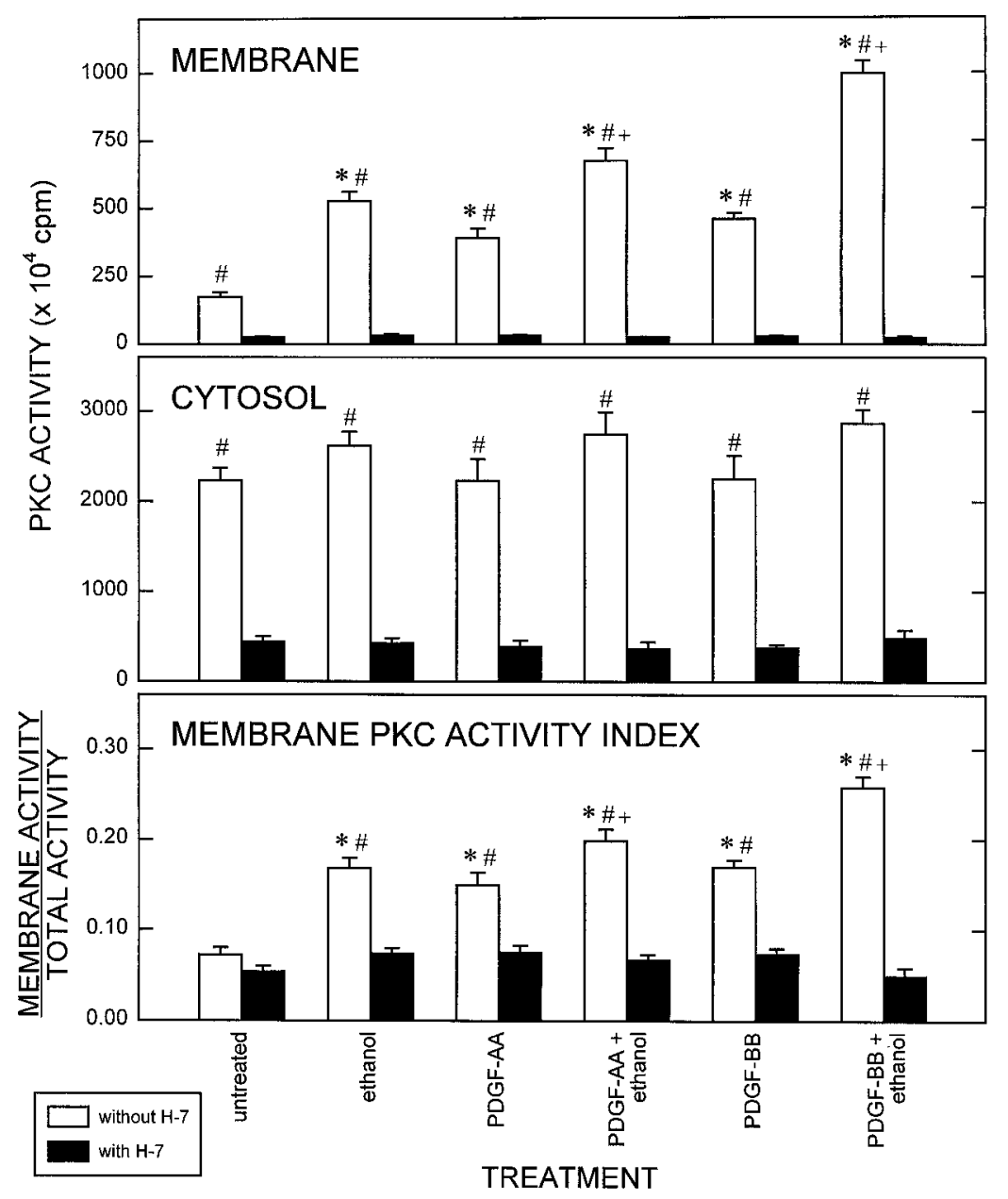

Figure 7. PKC activity. The effects of four substances (PDGF-AA, PDGF-BB, ethanol, and H-7) on PKC activity in the membranal (top) and cystolic fractions (middle) was determined. The graph at the bottom describes the effects of the four substances on the ratio of PKC activity in the membrane to the combined PKC activity in the membrane and cytosol. Statistically significant differences $(p<0.05)$ in comparisons relative to the untreated (control) cells are noted by an asterisk. Differences caused by H-7 pretreatment (i.e., comparing cells that were similarly treated with PDGF and/or ethanol) are identified by \#. Ethanol-induced differences for cells that were treated with the same growth factor are labeled with + . Each experiment was performed four times. scribed in human mesangial cells (Choudhury et al., 1993) and in smooth myocytes (Inui et al., 1994).

There is considerable cross-talk between the PKC and the Ras-Raf-MAPK pathways (Fig. 10). That is, activation of PKC can stimulate MAPK via a Ras-Raf-dependent or Ras-Rafindependent manner. For example, stimulation of PKC in lymphocytes inhibits Ras-GAP activity and increases the formation of Ras-GTP (Downward et al., 1990), and PKC can directly phosphorylate and activate Raf-1 in insect cells (Sözei et al., 1992) and fibroblasts (Kolch et al., 1993). In contrast, renal mesangial cells use a Ras-Raf-independent pathway; PKC activates neither Ras nor Raf-1, yet still it can affect MAPK (Li et al., 1995). Likewise, PKC can activate MAPK in $3 T 3$ cells by a mechanism independent of Raf (Schönwasser et al., 1998).

The presentation of the PKC is important in PDGF-mediated signaling. PDGF treatment significantly increases membranal PKC activity but has little effect on cytosolic activity. The relative amounts of PKC activity in the membrane and cytosol are important because they indicate the state of PKC mobilization. To become fully active, PKC must translocate from cytosolic pools to the membrane where it can interact with its phospholipid substrates (Kikkawa et al., 1982; Kraft et al., 1982; Neary et al., 1988). As most PKC activity in unstimulated astrocytes resides in the cytosol, PDGF must promote the translocation of PKC from the cytosol to the membrane. Similarly, both PDGF-AA and PDGF-BB induce a significant translocation of PKC from cytosol to membrane in vascular smooth muscle cells (Inui et al., 1994).

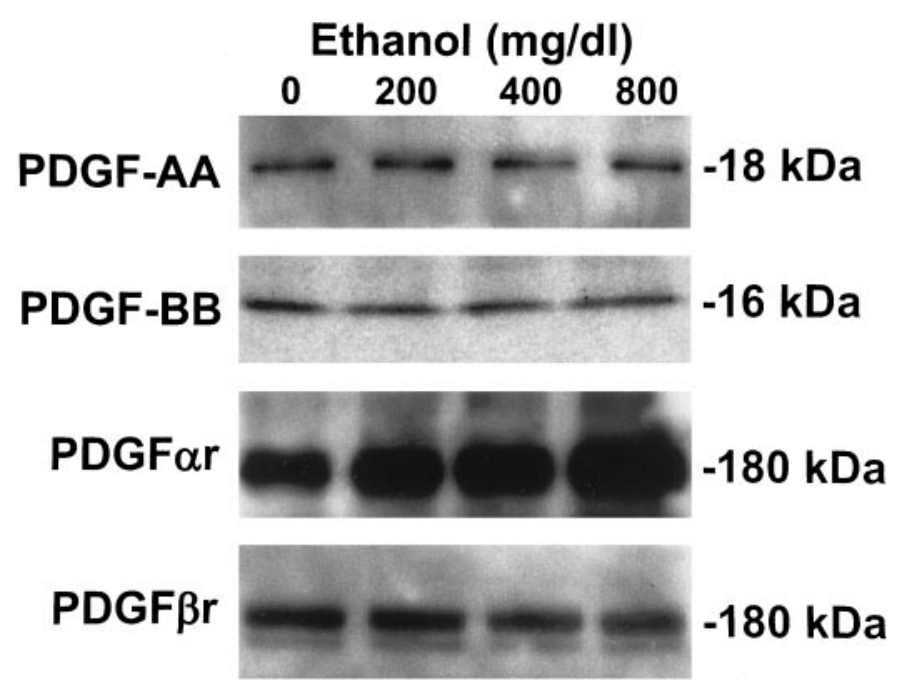

Figure 8. Expression of PDGF ligands and receptors. Top, The effect of ethanol on the expression of the $18 \mathrm{kDa}$ PDGF-AA and $16 \mathrm{kDa}$ PDGF-BB was analyzed with Western immunoblots. Astrocytes were treated with ethanol $(0-800 \mathrm{mg} / \mathrm{dl})$ for $3 \mathrm{~d}$. Thirty micrograms of cellular protein were loaded onto each lane. Bottom, Expression of the two PDGF receptor subunits was examined with immunoblots. Both receptors are $180 \mathrm{kDa}$ but could be distinguished using specific antibodies that had no cross-reactivity with the other subunit. 


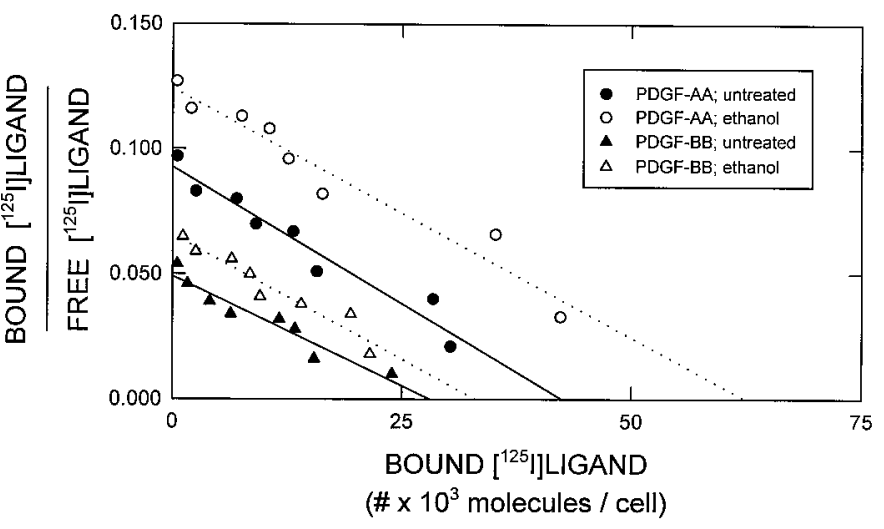

Figure 9. PDGF binding characteristics. The kinetics of PDGF-AA and PDGF-BB binding was assessed by a Scatchard analysis. Astrocytes were maintained in a medium containing $10 \%$ serum and treated with a PDGF ligand $(0$ or $30 \mathrm{ng} / \mathrm{ml})$ and/or ethanol $(0$ or $400 \mathrm{mg} / \mathrm{dl})$ for $3 \mathrm{~d}$. Each data point is the mean of four independent trials.

\begin{tabular}{lcc}
\hline \multicolumn{2}{l}{ Table 1. Scatchard analysis of PDGF binding } \\
& Untreated & Ethanol $(400 \mathrm{mg} / \mathrm{dl})$ \\
\hline$K_{\text {dPDGF-AA }}$ & $459 \pm 34 \mathrm{pM}$ & $503 \pm 27 \mathrm{pM}$ \\
$K_{\mathrm{dPDGF}-\mathrm{BB}}$ & $570 \pm 53 \mathrm{pM}$ & $502 \pm 48 \mathrm{pM}$ \\
$B_{\text {maxPDGF-AA }}$ & $42,600 \pm 2400 /$ cell & $62,300 \pm 4400 / \mathrm{cell} *$ \\
$B_{\text {maxPDGF-BB }}$ & $28,000 \pm 1700 /$ cell & $32,900 \pm 2400 / \mathrm{cell}$
\end{tabular}

Binding parameters were determined from the data of the binding assay described in Figure 9. The differences in PDGF binding parameters of ethanol-treated and untreated astrocytes were analyzed by a Student's $t$ test for independent samples. The asterisk denotes a statistically significantly difference $(p<0.05)$ in a comparison relative to the untreated cultures.

\section{Effect of ethanol on PDGF signaling}

\section{Receptor phosphorylation}

Ethanol inhibits the autophosphorylation of PDGF receptors, primarily the PDGF $\alpha$ r (Fig. 10). This is consistent with the selective ethanol-induced elimination of PDGF-AA-mediated cell proliferation. The effects on PDGF $\beta \mathrm{r}$-mediated activities are partial. This results from the ability of PDGF-BB to bind to either receptor isoform. The implication from these data is that the receptor kinase is the primary target of ethanol. This conclusion is supported by the finding that short-term treatment with ethanol has no effect on the amount of receptor expression.

The selective effect of ethanol on specific growth-factor receptors has been described for neural and non-neural cells. For example, ethanol inhibits the tyrosine phosphorylation of insulinlike growth factor I receptor (IGF-Ir) in NIH 3 T3 fibroblast cells; however, it does not affect the tyrosine phosphorylation of the structurally and functionally similar insulin receptor (Resnicoff et al., 1993). In fact, these authors posit that all ethanol-induced damage to cell proliferation is regulated by the IGF-Ir. The present results argue against the privileged position of the IGF-Ir and show that various receptors can mediate ethanol-induced damage. On the other hand, we must emphasize that ethanol does not affect all the activity of all mitogenic receptors (cf. the effects on the PDGF $\alpha \mathrm{r}$ and the PDGF $\beta \mathrm{r}$ ). Furthermore, ethanol also affects the tyrosine phosphorylation of the epidermal growth factor (EGF) receptor in human epidermoid carcinoma cells (Thurston and Shukla, 1992) but does not alter the tyrosine kinase activity of nerve growth factor (NGF) and basic fibroblast growth factor (bFGF) receptors in pheochromocytoma (PC12) cells (Roivainen et al., 1995). Thus, ethanol does not universally affect all receptors.

The specific target of ethanol currently is unknown. That is, a loss of PDGF-stimulated receptor tyrosine activity can result from one of three types of mutation: (1) a point mutation of the ATP-binding site, (2) a deletion of the C-terminal region, and (3) replacement of the membrane-spanning sequences (Escobedo et al., 1988). Direct ethanol-induced damage to the receptor at any of these loci may inhibit receptor kinase activity. Alternatively, ethanol may indirectly change tyrosine kinase activity by altering other protein kinases or phosphatases that regulate PDGF receptor tyrosine kinase.

\section{Ras-GAP association}

The association between the phosphorylated PDGF $\alpha$ r and RasGAP is inhibited by ethanol. In contrast, PDGF $\beta r-$ Ras-GAP association is unaffected by ethanol. These specific effects mirror the ethanol-induced alterations in PDGF receptor phosphorylation. Hence, blocking of the receptor kinase is transmitted through the next step of the signal transduction pathway.

\section{MAPK activation}

The present study shows that ethanol stimulates MAPK activity in cultured cortical astrocytes. It does so by effectively raising MAPK activity $74.0 \%$, i.e., increasing the set-point of "basal" activity. This change is achieved within $1 \mathrm{hr}$ of ethanol administration and maintained for at least 90 min more. A stimulatory effect of ethanol on MAPK has been also reported for PC12 cells (Roivainen et al., 1995) and embryonic hepatocytes (Reddy and Shukla, 1996). Such results are paradoxical in that stimulation of MAPK activity is considered a pro-proliferative event, yet ethanol, which is an anti-proliferative agent, also stimulates MAPK activity.

PDGF receptor autophosphorylation is inhibited by ethanol. Theoretically, if the receptor kinase-Ras-Raf pathway is the only way to effect MAPK activity, then ethanol-induced inhibition of receptor phosphorylation should depress PDGF-mediated signal transduction and PDGF-stimulated MAPK activity. Our empirical data, however, show that treatment with ethanol increases MAPK activity and potentiates PDGF-stimulated MAPK activity. On the basis of these findings, we conclude that ethanol can activate MAPK via a pathway that bypasses the PDGF receptors. Possibly, activation of this "alternative" pathway masks the ethanol-mediated inhibition of PDGF signaling.

Candidate key components in the ethanol-induced stimulation of MAPK are PKCs. Not only do PKCs regulate MAPK activity (see above), but they are activated by ethanol (Messing et al., 1991; DePetrillo and Liou, 1993; Roivainen et al., 1995). The present data indicate that ethanol promotes the translocation of PKC from the cytosol to the membrane. It is only after the growth factor has promoted the PKC to associate with the membrane that it can interact with its substrate. Likewise, Skwish and Shain (1990) show that ethanol increases the PKC activity in the membrane.

Ethanol increases MAPK activity in control and PDGF-treated astrocytes; such increases are transduced by the activation of PKC (Fig. 10). After all, H-7 completely eliminates the ethanolinduced stimulation of MAPK activity. Thus, ethanol chronically activates MAPK via a PKC-dependent pathway. On the other hand, ethanol inhibits the transient PDGF receptor-regulated activation of MAPK via a PKC-independent pathway. In fact, 


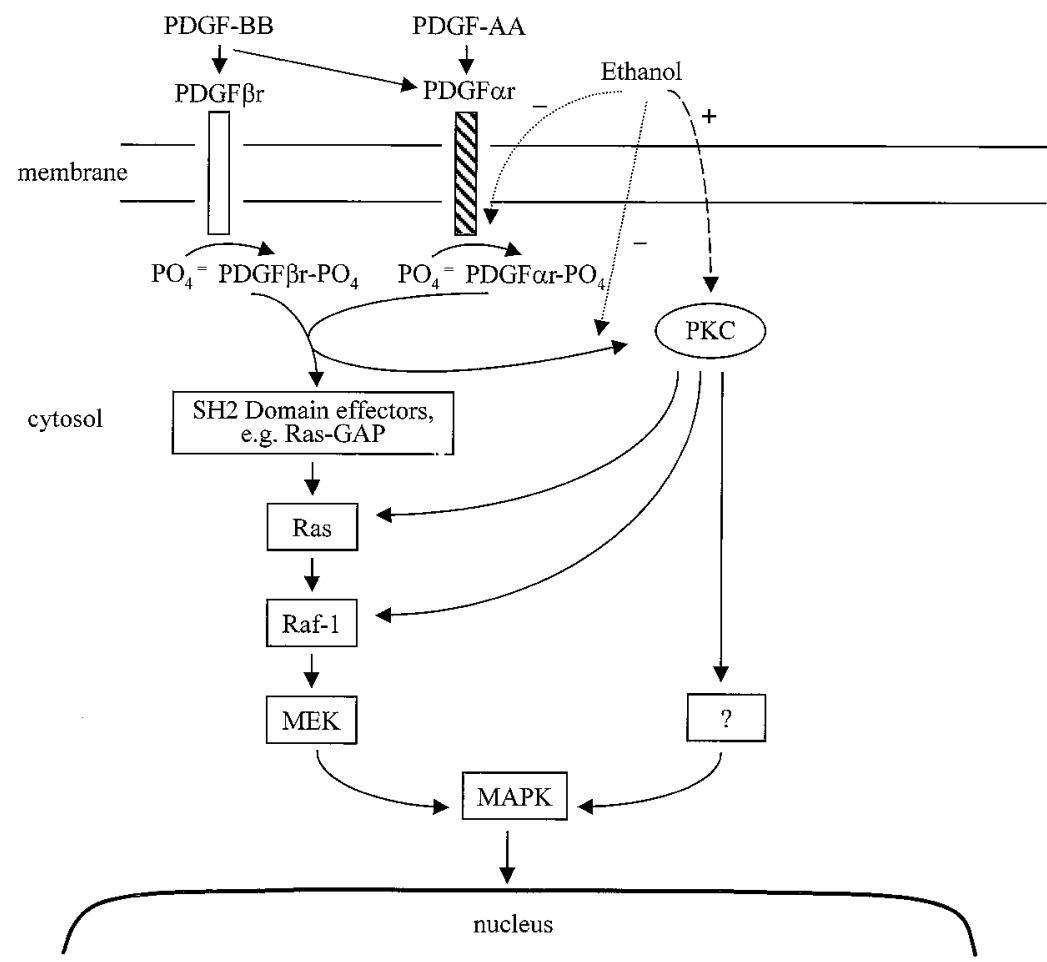

Figure 10. Schematic of signal transduction pathways of MAPK activation initiated by PDGF ligands. PDGF-AA induces only the tyrosine phosphorylation of PDGF $\alpha$ r, whereas PDGF-BB activates either receptor subunit. Receptor phosphorylation causes the activation of downstream effector molecules that contain an $\mathrm{SH} 2$ domain (e.g., RasGAP) and the sequential activation of Ras, Raf-1, MAPK kinase $(M E K)$, and eventually MAPK. Alternatively, receptor phosphorylation can activate PKC, which in turn, can stimulate MAPK by either by a direct effect on Ras-Raf- 1 or through an unknown intermediate molecule(s). Ethanol can affect receptor phosphorylation and PKC activity in the MAPK cascade. These positive (dashed lines) and negative (dotted lines) effects can alter the signal transduction cascade that ultimately leads to the stimulation or inhibition of MAPK. when PKC activity is blocked, ethanol totally eliminates PDGFAA-mediated activation of MAPK and partially inhibits PDGFBB-regulated MAPK activity. This differential effect parallels the effects of ethanol on the activation of PDGF receptor isoforms. We conclude, therefore, that (1) complete inhibition of PDGFAA-mediated MAPK activation results from interference with the activity of PDGF $\alpha$ r-ethanol selectively inhibits the autophosphorylation of the PDGF $\alpha$ r and the subsequent signal transduction - and (2) the incomplete blockade of PDGF-BB signaling on MAPK results from the ability of PDGF-BB to activate either the PDGF $\alpha$ r or PDGF $\beta \mathrm{r}$ and that PDGF $\beta \mathrm{r}$ is not affected by ethanol.

MAPK can be activated by mitogenic and growth inhibitory agents. The activation of MAPK may not be an all-or-none event; rather the critical event may be defined by the duration of activation. For example, NGF and bFGF, inhibitors of PC12 cell proliferation, induce chronic MAPK activation for several hours. In contrast, EGF, a stimulator of PC12 cell proliferation, induces only transient (<30 min) MAPK activation (Qiu and Green, 1992; Tombes et al., 1998). Depending on cell types, NGF may induce either acute or chronic activation of MAPK. When NGF acutely activates the MAPK of rat hepatocytes, it stimulates DNA synthesis in these cells (Tombes et al., 1998). In contrast, when MAPK is chronically activated in hepatocytes via infection with an inducible estrogen receptor-Raf-1 fusion protein, DNA synthesis is inhibited. Furthermore, both transforming growth factor $\beta 1$ (TGF $\beta 1)$ and ethanol are potent growth inhibitory agents for B104 neuroblastoma cells (Luo and Miller, 1999). They induce a chronic state of increased MAPK activity. Blocking MAPK activity in theses cells completely reverses TGF $\beta 1$ - and ethanol-mediated growth inhibition. Therefore, acute activation of ERK promotes cell proliferation, and chronic activation of ERK inhibits this process. It can be deduced that ethanol impairs PDGF-mediated cell proliferation by inhibition of acute MAPK activation and a concurrent promotion of chronic activation.

\section{Ligand and receptor expression}

Our results and those of Silberstein et al. (1996) show that cultured astrocytes express both PDGF monomers. Chronic ethanol exposure does not affect ligand production. Moreover, it does not affect the affinity of the ligand to bind with its receptor(s). This lack of an ethanol-induced effect contrasts with the rapid effects of ethanol on signal transduction.

Astrocytes express both PDGF receptor isoforms. Ethanol exposure selectively alters the expression of PDGF $\alpha$ r. The expression of a PDGF receptor can be influenced by the availability of PDGF (Eriksson et al., 1991; Bejcek et al., 1993). Ethanol alters neither ligand expression nor binding affinity. Therefore, we must conclude that the altered receptor expression is not a response to changed ligand availability, but rather it reflects a direct effect of ethanol on the receptor. Interestingly, only the expression of the PDGF $\alpha \mathrm{r}$ is affected by ethanol. Ethanol upregulates PDGF $\alpha \mathrm{r}$ expression, as is evident in immunoblots and saturation binding assays. It is appealing to speculate that this is a compensatory response to the ethanol-induced inhibition of this receptor subtype because (1) ethanol preferentially inhibits the tyrosine phosphorylation of the PDGF $\alpha$ r and PDGF $\alpha$ r-mediated signal transduction and (2) chronic ethanol exposure (3 d) is required to induced receptor upregulation; acute ethanol exposure (1 hr) does not affect the expression of PDGF $\alpha$ r. Other data also indicate that the PDGF $\alpha \mathrm{r}$ is more susceptible to environmental modulation than the PDGF $\beta$ r. For example, TGF $\beta 1$, a potent anti-mitogenic agent, selectively reduces the expression of PDGF $\alpha \mathrm{r}$ without affecting PDGF $\beta$ r (Paulsson et al., 1993; Bonner et al., 1995).

\section{Conclusions}

Various in vivo and in vitro data show that growth factor receptors are targets of ethanol toxicity. High- and low-affinity neurotrophin receptors (TrkA, TrkB, and p75) are sensitive to ethanol in vivo (Aloe and Tirassa, 1992; Valles et al., 1994; Baek et al., 1996; 
Dohrman et al., 1997). Ethanol exposure also alters the in vitro expression of growth factor receptors such as the bFGF receptor, EGF receptor, insulin receptor, IGF-Ir, and p75 (Rifkin et al., 1983; Wang et al., 1992, 1994; Resnicoff et al., 1993; Luo et al., 1996; Luo and Miller, 1997b; Seabold et al., 1998).

PDGF and PDGF receptors are widely expressed in neurons and glia in both the developing and mature nervous systems (Valenzuela et al., 1997). In addition to its mitogenic effect on glia, recent studies show that PDGF is also an important neurotrophic and neuroprotective agent for neurons in the CNS (Valenzuela et al., 1997). The present study shows that ethanol inhibits PDGF-mediated astrocyte proliferation and alters PDGF signaling by blocking receptor kinase activity. The results show that (1) ethanol-induced interference with the action of this important growth factor is a critical mechanism underlying ethanol-induced disruptions in cell proliferation, (2) ethanol raises the set-point for basal MAPK activity, thereby changing growth factor-mediated increases in MAPK activity into an antiproliferative signal, and (3) ethanol is a valuable tool for dissecting the mechanism(s) by which PDGF regulates cell proliferation.

\section{REFERENCES}

Adickes ED, Mollner TJ, Lockwood SK (1988) Closed chamber system for delivery of ethanol to cell cultures. Alcohol Alcohol 23:377-381.

Aloe L, Tirassa P (1992) The effect of long-term alcohol intake on brain NGF-target cells of aged rats. Alcohol 9:299-304.

Baek JK, Heaton MB, Walker DW (1996) Up-regulation of high-affinity neurotrophin receptor, trkB-like protein on Western blots of rat cortex after chronic ethanol treatment. Mol Brain Res 40:161-164.

Bejcek BE, Voravud N, Deuel TF (1993) Biosynthesis and processing of the platelet-derived growth factor type $\alpha$ receptor. Biochem Biophys Res Commun 196:69-78.

Bonner JC, Badgett A, Lindroos PM, Osornio-Vargas, AR (1995) Transforming growth factor $\beta 1$ downregulates the platelet-derived growth factor $\alpha$-receptor subtype on human lung fibroblast in vitro. Am J Respir Cell Mol Biol 13:496-505.

Bornfeldt KE, Raines EW, Graves LM, Skinner MP, Krebs EG, Ross R (1995) Platelet-derived growth factor: distinct signal transduction pathways associated with migration versus proliferation. Ann NY Acad Sci 766:416-430.

Bowen-Pope DF, Hart CE, Seifert RA (1989) Sera and conditioned media contain different isoforms of platelet-derived growth factor (PDGF) which bind to different classes of PDGF receptor. J Biol Chem 264:2502-2508.

Buchdunger E, Zimmermann J, Mett H, Meyer T, Müller M, Regenass U, Lydon NB (1995) Selective inhibition of platelet-derived growth factor signal transduction pathway by a protein-tyrosine kinase inhibitor of the 2-phenylaminopyrimidine class. Proc Natl Acad Sci USA 92:2558-2562.

Choudhury GG, Biswas P, Grandaliano G, Abbound HE (1993) Involvement of PKC- $\alpha$ in PDGF-mediated mitogenic signaling in human mesangial cells. Am J Physiol 265:F634-F642.

Claesson-Welsh L (1994) Platelet-derived growth factor receptor signal. J Biol Chem 269:32023-32026.

Davies DL, Vernadakis A (1984) Effects of ethanol on cultured glial cells: proliferation and glutamine synthetase activity. Dev Brain Res 16:27-35.

DePetrillo PB, Liou C (1993) Ethanol exposure increases total protein kinase $\mathrm{C}$ activity in human lymphocytes. Alcohol Clin Exp Res 17:351-354.

Dohrman DP, West JR, Pantazis NJ (1997) Ethanol reduces expression of the nerve growth factor receptor, but not nerve growth factor protein levels in the neonatal rat cerebellum. Alcohol Clin Exp Res 21:882-893.

Downward J, Graves JD, Warne PH, Rayter S, Cantrell DA (1990) Stimulation of p21ras upon T-cell activation. Nature 346:719-723.

Ek B, Heldin CH (1982) Characterization of a tyrosine specific kinase activity in human fibroblast membranes stimulated by platelet-derived growth factor. J Biol Chem 257:10486-10491.

Eriksson A, Nister M, Leveen P, Westermark B, Heldin C-H, ClaessonWelsh L (1991) Induction of platelet-derived growth factor $\alpha$ - and $\beta$-receptor mRNA and protein by platelet-derived growth factor BB. J Biol Chem 266:21138-21144.

Escobedo J, Barr P, Williams L (1988) Role of tyrosine kinase and membrane-spanning domain in signal transduction by the plateletderived growth factor receptor. Mol Cell Biol 8:5126-5131.

Guerri C, Sáez R, Sancho-Tello M, de Aquilera EM, Renau-Piqueras J (1990) Ethanol alters astrocyte development: a study of critical periods using primary cultures. Neurochem Res 15:559-565.

Hart CE, Bailey M, Curtis DA, Osborn S, Raines E, Ross R, Forstrom JW (1990) Purification of PDGF-AB and PDGF-BB from human platelet extracts and identification of all three PDGF dimers in human platelets. Biochemistry 29:166-172.

Hart KC, Galvin BD, Donoghue DJ (1995) Structure and function of the platelet-derived growth factor family and their receptors. In: Genetic engineering (Setlow JK, ed), pp 181-207. New York: Plenum.

Hidaka H, Inagaki M, Kawamoto S, Sasaki Y (1984) Isoquinolinesulfonamides, novel and potent inhibitors of cyclic nucleotide dependent protein kinase and protein kinase C. Biochemistry 23:5036-5041.

Inui H, Kitami Y, Tani M, Kondo T, Inagami T (1994) Differences in signal transduction between platelet-derived growth factor (PDGF) and receptors in vascular smooth muscle cells. J Biol Chem 269:30546-30552.

Kennedy LA, Mukerji S (1986) Ethanol neurotoxicity. I. Direct effects on replicating astrocytes. Neurobehav Toxicol Teratol 18:11-15.

Kikkawa U, Takai Y, Minakuchi R, Inohara S, Nishizuka Y (1982) Calcium-activated, phospholipid-dependent protein from rat brain. Subcellular distribution, purification and properties. J Biol Chem 257:13341-13348.

Kohler N, Lipton A (1974) Platelets as a source of fibroblasts growthpromoting activity. Exp Cell Res 87:297-301.

Kolch W, Heidecker G, Kochs G, Hummel R, Vahidi H, Mischak H, Finkenzeller G, Marmé D, Rapp UR (1993) Protein kinase C alpha activates raf-1 by direct phosphorylation. Nature 364:249-252.

Kovalenko M, Gazit A, Böhmer A, Rorsman C, Ronnstrand L, Heldin C-H, Waltenberger J, Böhmer F-D, Levitzki A (1994) Selective platelet-derived growth factor receptor kinase blockers reverse cistransformation. Cancer Res 54:6106-6114.

Kraft AS, Anderson WB, Cooper HL, Sando JJ (1982) Decrease in cytosolic calcium/phospholipid-dependent protein kinase activity following phorbol ester treatment of EL4 thymoma cells. J Biol Chem 257:13193-13196.

Li X, Zarinetchi F, Schrier RW, Nemeroff RA (1995) Inhibition of MAP kinase by prostaglandin E2 and forskolin in rat renal mesangial cells. Am J Physiol 269:C986-C991.

Lowry OH, Rosebrough NJ, Farr AL, Randall RJ (1951) Protein measurement with phenol reagent. J Biol Chem 193:265-273.

Luo J, Miller MW (1997a) Basic fibroblast growth factor- and plateletderived growth factor-mediated cell proliferation in B104 neuroblastoma cells: effect of ethanol on cell cycle kinetics. Brain Res 770:139-150.

Luo J, Miller MW (1997b) Differential sensitivity of human neuroblastoma cell lines to ethanol: correlation with their proliferative responses to mitogenic growth factors and expression of growth factor receptors. Alcohol Clin Exp Res 21:1186-1194.

Luo J, Miller MW (1998) Growth factor-mediated neural proliferation: a target of ethanol toxicity. Brain Res Rev 27:157-167.

Luo J, Miller MW (1999) Transforming growth factor (TGF) $\beta 1$ mediated cell proliferation and expression of neural adhesion molecule in B104 neuroblastoma cells: differential effects of ethanol. J Neurochem 72:2286-2293.

Luo J, West JR, Pantazis NJ (1996) Ethanol exposure reduces the expression of low affinity nerve growth factor receptor (p75) in pheochromocytoma (PC12) cells. Brain Res 737:34-44.

Messing RO, Petersen PJ, Henrich CJ (1991) Chronic ethanol exposure increases levels of protein kinase $\mathrm{C}$ delta and epsilon and protein kinase $\mathrm{C}$-mediated phosphorylation in cultured neural cells. J Biol Chem 266:23428-23432.

Miller MW (1992) Effects of prenatal exposure to ethanol on cell proliferation and neuronal migration. In: Development of the central nervous system: effects of alcohol and opiates (Miller MW, ed), pp 47-69. New York: Wiley-Liss.

Miller MW, Potempa G (1990) Numbers of neurons and glia in mature rat somatosensory cortex: effects of prenatal exposure to ethanol. J Comp Neurol 293:92-102. 
Mooney SM, Miller MW (1999) Ethanol and neuronal death in the developing brain. Research Signposts, in press.

Munson PJ, Rodbard D (1980) Ligand: a versatile computerized approach for characterization of ligand-binding system. Anal Biochem 107:220-239.

Nagano N, Aoyagi M, Hirakawa K (1993) Extracellular matrix modulates the proliferation of rat astrocytes in serum-free culture. Glia 8:71-76.

Neary JT, Norenberg LO, Norenberg MD (1988) Protein kinase C in primary astrocyte cultures: cytoplasmic localization and translocation by a phorbol ester. J Neurochem 50:1179-1184.

Nishizuka Y (1992) Intracellular signaling by hydrolysis of phospholipids and activation of protein kinase C. Science 258:607-614.

Pantazis NJ, Dohrman DP, Luo J, Goodlett CR, West JR (1992) Alcohol reduces the number of pheochromocytoma (PC12) cells in culture. Alcohol 9:171-180.

Paulsson Y, Karlsson C, Heldin CH, Westermark B (1993) Densitydependent inhibitory effect of transforming growth factor- $\beta 1$ on human fibroblasts involves the down-regulation of platelet-derived growth factor $\alpha$-receptors. J Cell Physiol 157:97-103.

Prins BA, Weber MJ, Hu R-M, Pedram A, Daniels M, Levin ER (1996) Atrial natriuretic peptide inhibits mitogen-activated protein kinase through the clearance receptor. J Biol Chem 271:14156-14162.

Qiu M-S, Green SH (1992) NGF and EGF rapidly activate p21 ras in PC12 cells by distinct, convergent pathways involving tyrosine phosphorylation. Neuron 9:705-717.

Reddy MA, Shukla SD (1996) Potentiation of mitogen-activated protein kinase by ethanol in embryonic liver cells. Biochem Pharmacol 51:661-668.

Reddy UR, Pleasure D (1992) Expression of platelet-derived growth factor (PDGF) and PDGF receptor genes in the developing rat brain. J Neurosci Res 31:670-677.

Resnicoff M, Sell C, Ambrose D, Baserga R, Rubin R (1993) Ethanol inhibits the autophosphorylation of insulin-like growth factor I (IGF-I) receptor and IGF-I-mediated proliferation of 3T3 cells. J Biol Chem 268:21777-21782.

Rifkin RM, Todd WW, Toothaber DR, Sussman A, Trowbridge M, Draznin B (1983) Effects of in vivo and in vitro alcohol administration on insulin binding and glycogenesis for isolated rat hepatocytes. Ann Nutr Metab 27:313-319.

Roivainen R, Hundle B, Messing RO (1995) Ethanol enhances growth factor activation of mitogen-activated protein kinases by a protein kinase C-dependent mechanism. Proc Natl Acad Sci USA 92:1891-1895.

Rosenthal H (1967) Graphic method for the determination and presentation of binding parameters in a complex system. Anal Biochem 20:525-532.

Ross R, Glomset J, Kariya, B, Harker L (1974) A platelet-dependent serum factor that stimulates the proliferation of arterial smooth muscle cells in vitro. Proc Natl Acad Sci USA 71:1207-1210.

Satoh T, Fantl WJ, Escobedo JA, Williams LT, Kaziro Y (1993) Platelet-derived growth factor receptor mediates activation of ras through different signaling pathways in different cell types. Mol Cell Biol 13:3706-3713.

Seabold GK, Luo J, Miller MW (1998) Effects of ethanol on neurotrophin-mediated survival and receptor expression in cultured cortical neurons. Dev Brain Res 108:139-145.
Seifert RA, Koppen A, Bowen-Pope DF (1993) PDGF-AB requires PDGF receptor-subunits for high-affinity, but not for low-affinity, binding and signal transduction. J Biol Chem 268:4473-4480.

Silberstein FC, Simone RD, Levi G, Aloisi F (1996) Cytokine-regulated expression of platelet-derived growth factor gene and protein in cultured human astrocytes. J Neurochem 66:1409-1417.

Skwish S, Shain W (1990) Ethanol and diolein stimulate PKC translocation in astroglial cells. Life Sci 47:1037-1042.

Schönwasser DC, Marais RM, Marshall CJ, Parker PJ (1998) Activation of the mitogen-activated protein kinase/extracellular signal-regulated kinase pathway by conventional, novel, and atypical protein kinase $\mathrm{C}$ isotypes. Mol Cell Biol 18:790-798.

Snyder AK, Singh SP, Ehmann S (1992) Effects of ethanol on DNA, RNA and protein synthesis in rat astrocyte cultures. Alcohol Clin Exp Res 16:295-300.

Sözei O, Vollmer K, Liyanage, M, Frith, D, Kour G, Mark GE, Stable S (1992) Activation of the c-raf protein kinase by protein kinase C phosphorylation. Oncogene 7:2259-2262.

Thurston AW, Shukla S (1992) Ethanol modulates epidermal growth factor-stimulated tyrosine kinase and phosphorylation of PLCgamma1. Biochem Biophys Res Commun 185:1062-1068.

Tombes RM, Auer KL, Mikkelsen R, Valerie K, Wymann MP, Marshall J, McMahon M, Dent P (1998) The mitogen-activated protein (MAP) kinase cascade can either stimulate or inhibit DNA synthesis in primary cultures of rat hepatocytes depending upon whether its activation is acute/phasic or chronic. Biochem J 330:1451-1460.

Ullrich A, Schlessinger J (1990) Signal transduction by receptors with tyrosine kinase activity. Cell 61:203-212.

Uren A, Yu J-C, Gholami NS, Pierce JH, Heidaran MA (1994) The alpha PDGF tyrosine kinase mediates locomotion of two different cell types through chemotaxis and chemokinesis. Biochem Biophys Res Commun 204:628-634.

Valenzuela CF, Kazlauskas A, Weiner JL (1997) Roles of plateletderived growth factor in developing and mature nervous systems. Brain Res Rev 24:77-89.

Valles S, Lindo L, Montoliu C, Renau-Piqueras J, Guerri C (1994) Prenatal exposure to ethanol induces changes in nerve growth factor and its receptor in proliferating astrocytes in primary culture. Brain Res 656:281-286.

Wang SL, Jacober L, Wu-Wang CY, Slomiany A, Slomiany BL (1992) Ethanol-induced structural and functional alterations of epidermal growth factor receptor in buccal mucosa. Intl J Biochem 24:85-90.

Wang SL, Wu-Wang CY, Slomiany A, Slomiany BL (1994) Effects of acute ethanol treatment on epidermal growth factor receptor in rat stomach. Alcohol 11:11-15.

Westermark B, Wasteson A (1976) A platelet factor stimulating human normal glial cells. Exp Cell Res 98:170-174.

Zhang FX, Hutchins JB (1997) Protein phosphorylation in response to PDGF stimulation in cultured neurons and astrocytes. Dev Brain Res 99:216-225.

Zhang XF, Settleman J, Kyriakis JM, Takeuchi-Suzuki E, Elledge SJ, Marshall MS, Bruder JT, Rapp UR, Avruch J (1993) Normal and oncogenic $\mathrm{p} 21$ ras proteins bind to the amino-terminal regulatory domain of c-raf-1. Nature 364:308-313. 